\title{
Synthesis, Structural Analysis, and Biological Activities of Some Imidazolium Salts
}

\author{
Gühergül Uluçam (D) and Murat Turkyilmaz \\ Department of Chemistry, Trakya University, 22030 Edirne, Turkey \\ Correspondence should be addressed to Gühergül Uluçam; gulergul@trakya.edu.tr
}

Received 11 February 2018; Revised 11 April 2018; Accepted 17 April 2018; Published 22 May 2018

Academic Editor: Rais A. Khan

Copyright (C) 2018 Gühergül Uluçam and Murat Turkyilmaz. This is an open access article distributed under the Creative Commons Attribution License, which permits unrestricted use, distribution, and reproduction in any medium, provided the original work is properly cited.

Four newly synthesized imidazolium salts were characterized by nuclear magnetic resonance, vibrational spectra, and mass spectra. Then, the density functional theory calculations were performed to obtain the molecular configurations on which the theoretical nuclear magnetic resonance and infrared spectra were consequently obtained. The comparison of calculated spectra with the experimental spectra for each molecule leads to the conclusion that the theoretical results can be assumed to be a good approach to their molecular configurations. The in vitro biological activities of the salts on the selected bacteria and cancer cell lines were determined by using the broth dilution method according to Clinical and Laboratory Standards Institute guidelines. The 1,3-bis(2-hydroxyethyl) imidazolidinium bromide and 3-(2-ethoxy-2-oxoethly)-1-(3-aminopropyl)-1H-imidazol-3-ium bromide showed efficiency on Bacillus cereus ATCC 11778. The 3-bis(2-carboxyethyl)-4-methyl-1-H-imidazol-3-ium bromide was effective on HeLa while a similar effect was observed on Hep G2 with 3-(2-carboxyethyl)-1-(3-aminopropyl)-1Himidazol-3-ium bromide.

\section{Introduction}

Imidazole rings are building blocks in amino acids [1] together with the fact that their membership in the development of new antifungal drugs $[2,3]$ and antibiotics $[4,5]$ are crucial. Its derivatives are widely used in other medicinal applications [6]. The pregnane derivatives with imidazole moiety and triazole moiety, for example, were tested on the prostate, breast, and lung cancer cell lines, and dose-effective proliferation of the cells was determined [7]. Similarly, the novel hybrid compounds of imidazole scaffold-based 2-benzylbenzofloran have been prepared and used in cytotoxic activity studies on various cancer cell lines [8].

As a five-membered aromatic ring containing two nonadjacent nitrogen atoms [9], imidazole is also subjected to various computational chemistry research beyond its biological applications. Its ability to capture $\mathrm{CO}_{2}$ was determined in the investigations of the greenhouse effect compensation in the framework of van der Waals bonded host-guest relation [10]. The hydroxyl conductivity in polymembranes based on imidazole salts was simulated using radial distribution functions and found that the imidazole groups provide better conductivity than that of water and methanol [11]. Moreover, the specific imidazole derivatives exhibited good cross section values for two-photon absorption [12]. The detoxification of phosphotriesters by imidazole rings was clarified comparing the same effects with methylimidazoles depending on the methyl positioning [13].

$\mathrm{N}$-Heterocyclic carbenes (NHCs) are the imidazolebased carbene groups which are isolated and crystallized by the deprotonation of imidazole salts [14]. Also, the imidazole salts naturally transform into NHCs over metal complex building reactions, as exampled on the synthesis and characterization of the silver-NHC complexes [15] and the iron-imidazole salts [16].

The constitution and functions of imidazole ligands in organometallic chemistry and inorganic chemistry have been widely studied, and these particular researches have been evaluated as a scientific competition field due to its importance in the related industry [17]. Also, they are set as 
alternative to usual ligands in the carbon-carbon coupling reactions of the pharmaceutical reagents [18]. The synthesis and spectroscopic characterizations of four new NHC ligands, namely, 1,3-bis(2-hydroxyethyl) imidazolidinium bromide $\left(L_{\mathrm{A}}\right)$, 3-(2-ethoxy-2-oxoethly)-1-(3-aminopropyl)-1H-imidazol-3-ium bromide $\left(L_{\mathrm{B}}\right)$, 1,3-bis(2-carboxyethyl)-4-methyl-1H-imidazol-3ium bromide $\left(L_{\mathrm{C}}\right)$, and 3-(2-carboxyethyl)-1-(3-aminopropyl)1 H-imidazol-3-ium bromide $\left(L_{\mathrm{D}}\right)$ were exhibited in this study. Using their nuclear magnetic resonance (NMR) and infrared (IR) spectra, the molecular properties of the ligands were obtained. Also, the in vitro biological activities of the synthesized molecules were presented.

\section{Materials and Methods}

2.1. Instrumentation and Methods. The ${ }^{1} \mathrm{H}$ and ${ }^{13} \mathrm{C} \mathrm{NMR}$ spectra of the compounds in deuterium oxide $\left(\mathrm{D}_{2} \mathrm{O}\right)$ were recorded on Varian $300 \mathrm{MHz}$ and Varian $75.5 \mathrm{MHz}$, respectively. The IR spectra by $\mathrm{KBr}$ pellets were recorded in the range $450-4000 \mathrm{~cm}^{-1}$ by a PerkinElmer BXII spectrometer. The mass spectra were acquired by the electron impact technique using a Thermo Finnegan Trace DSQ GC/MS. Elemental analyses for $\mathrm{C}, \mathrm{H}$, and $\mathrm{N}$ were realized on the dried samples using a PerkinElmer $2400 \mathrm{CHN}$ analyzer. The absorbance measurements in determining the biological activities of the material were carried out in Thermo Scientific Multiskan Go multiplate spectrophotometer.

\subsection{Synthesis}

2.2.1. 1,3-Bis(2-hydroxyethyl) Imidazolidinium Bromide, $L_{A}$. Imidazole $(10 \mathrm{mmol}, 0.68 \mathrm{~g})$ was dissolved in tetrahydrofuran (THF), and bromoethanol (22 mmol, $2.75 \mathrm{~g}$ ) was added as the mixture was stirred for 20 hours. The completion of the reaction was monitored by thin-layer chromatography (TLC) in ethyl acetate/hexane (1:5) analyses, and the solid residue was filtered out with a sintered glass funnel. The solvent in the filtrate was evaporated using a rotary evaporator, and the product was dried in a vacuum desiccator. After that, the product was purified by column chromatography (ethyl acetate/hexane, 1:5). The best yield was obtained when the reaction was carried out at room temperature with a $1: 2$ mole ratio of the reagents. $1.54 \mathrm{~g}$ of the final product was obtained with $65 \%$ yield. It was in yellowish liquid form. The elemental analyses result for $L_{\mathrm{A}}$ with the chemical formula $\mathrm{C}_{7} \mathrm{H}_{13} \mathrm{BrN}_{2} \mathrm{O}_{2}$ are $\mathrm{C}, 35.46 \% ; \mathrm{H}$, $5.53 \%$; and $\mathrm{N}, 11.82 \%$; found: C, $35.35 \%$; $\mathrm{H}, 5.43 \%$; and $\mathrm{N}$, $11.73 \%$. The mass spectroscopy reads $(m / z) 158.22(\mathrm{M}+\mathrm{H})^{+}$ which is consistent with the expected molecular weight.

2.2.2. 3-(2-Ethoxy-2-oxoethly)-1-(3-aminopropyl)-1H-imidazol3-ium Bromide, $L_{B}$. 3-(1H-imidazol-1-yl)propan-1-amine $(10 \mathrm{mmol}, 1.27 \mathrm{~g})$ was dissolved in THF and stirred at room temperature, and then, ethyl bromoacetate $(11 \mathrm{mmol}$, $1.837 \mathrm{~g}$ ) was added with a $1: 1$ mole ratio. The mixture was stirred for $15 \mathrm{hr}$. The completion of the reaction was monitored by thin layer chromatography (TLC) in ethyl acetate/hexane $(1: 5)$ analyses. The solvent was evaporated in a rotary evaporator, and the substance was kept under vacuum in a desiccator. After that, the product was purified by column chromatography (ethyl acetate/hexane, 1:5). It was pale brown oily liquid. $0.94 \mathrm{~g}$ of the final product was obtained with $32 \%$ yield. The elemental analyses result for $L_{\mathrm{B}}$ with the chemical formula $\mathrm{C}_{10} \mathrm{H}_{18} \mathrm{BrN}_{3} \mathrm{O}_{2}$ are $\mathrm{C}, 41.11 \%$; $\mathrm{H}, 6.21 \%$; and N, 14.38\%; found: C, 39.93\%; H, 6.35\%; N, and $14.21 \%$. The mass spectroscopy result reads $(m / z) 213.12(\mathrm{M}+\mathrm{H})^{+}$which is consistent with the expected molecular weight.

\subsubsection{1,3-Bis(2-carboxyethyl)-4-methyl-1H-imidazol-3-ium} Bromide, $L_{C}$. The procedure applied in the synthesis of $L_{\mathrm{A}}$ was also used for the synthesis of $L_{\mathrm{C}}$ by replacing imidazole and bromoethanol with 4-methylimidazole (10 mmol, $0.82 \mathrm{~g})$ and 3-bromopropionic acid $(22 \mathrm{mmol}$, $3.366 \mathrm{~g}$ ), respectively. After that, the product was purified by column chromatography (ethyl acetate/hexane, $1: 5$ ). It was in white solid form. $1.48 \mathrm{~g}$ of the final product was obtained with $48 \%$ yield. The elemental analyses result for $L_{C}$ with the chemical formula $\mathrm{C}_{10} \mathrm{H}_{15} \mathrm{BrN}_{2} \mathrm{O}_{4}$ are $\mathrm{C}, 39.10 \% ; \mathrm{H}, 4.92 \%$; and N, 9.12\%; found: C, 38.97\%; H, 4.77\%; and N, $19.22 \%$. The mass spectroscopy result reads $(m / z) 227.68(\mathrm{M}+\mathrm{H})^{+}$ which is consistent with the expected molecular weight.

\subsubsection{3-(2-Carboxyethyl)-1-(3-aminopropyl)-1H-imidazol-3-} ium Bromide, $L_{D}$. The procedure applied in the synthesis of $L_{\mathrm{B}}$ was also used for the synthesis of $L_{\mathrm{D}}$ by replacing ethyl bromoacetate with 3-bromopropanoic acid (11 mmol, $1.683 \mathrm{~g}$ ), respectively. The product was purified by column chromatography (ethyl acetate/hexane, 1:5). It was pale brown oily liquid. $1.22 \mathrm{~g}$ of the final product was obtained with $44 \%$ yield. The elemental analyses result for $L_{\mathrm{D}}$ with the chemical formula $\mathrm{C}_{9} \mathrm{H}_{16} \mathrm{BrN}_{3} \mathrm{O}_{3}$ are C, 38.86\%; H.5.80\%; and N, 15.11\%; found: C, 38.77\%; H, 5.63\%; and N, $15.23 \%$. The mass spectroscopy result reads $(m / z) 198.25(\mathrm{M}+\mathrm{H})^{+}$ which is consistent with the expected molecular weight.

\subsection{Biological Activities}

2.3.1. Antibacterial Activity. Broth microdilution method as in the guidelines of Clinical Laboratory Standards Institute was applied to determine the antibacterial activities of the $L_{\mathrm{A}}$, $L_{\mathrm{B}}, L_{\mathrm{C}}$, and $L_{\mathrm{D}}$ on the Gram-negative bacteria (Escherichia coli ATCC 25922, Escherichia coli 0157:H7, and Salmonella typhimurium ATCC 14028), Gram-positive bacteria (Bacillus cereus ATCC 11778, Staphylococcus aureus ATCC 25923, and Listeria monocytogenes ATCC 19115), and standard yeast Candida albicans ATCC 10231. The bacteria and yeast were obtained from the American Type Culture Collection. The incubations were done in Tryptic Soy Broth medium at $37^{\circ} \mathrm{C}$ for $24 \mathrm{hr}$ in the scale of McFarland 0.5. The antibiotic controls were carried by gentamicin on Bacillus cereus ATCC 1177 and amphotericin-b on Candida albicans ATCC 10231, while ampicillin was used on the other bacteria samples. For sterilization purposes, the antibiotic solutions and the stock solution of the chemicals were filtered through a $0.45 \mu \mathrm{m}$ sterile filter. The solvent in which the test compounds 


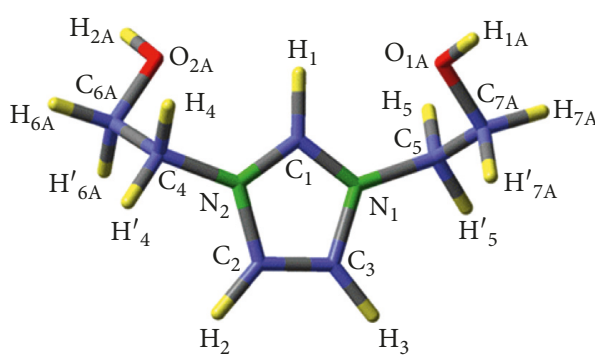

(a)

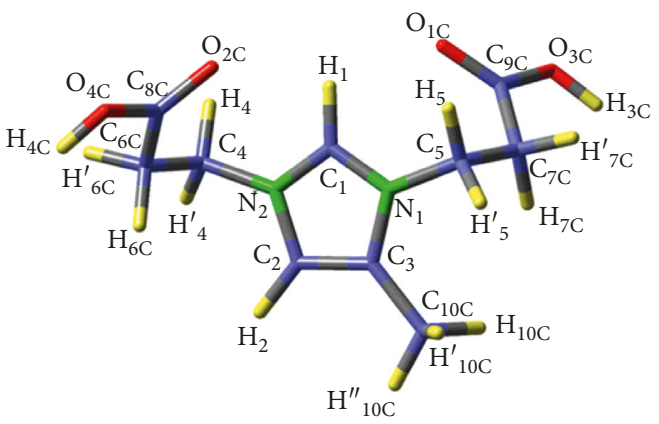

(c)

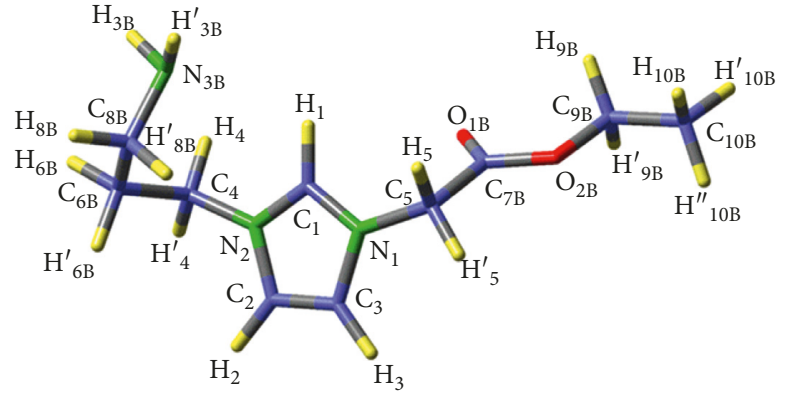

(b)

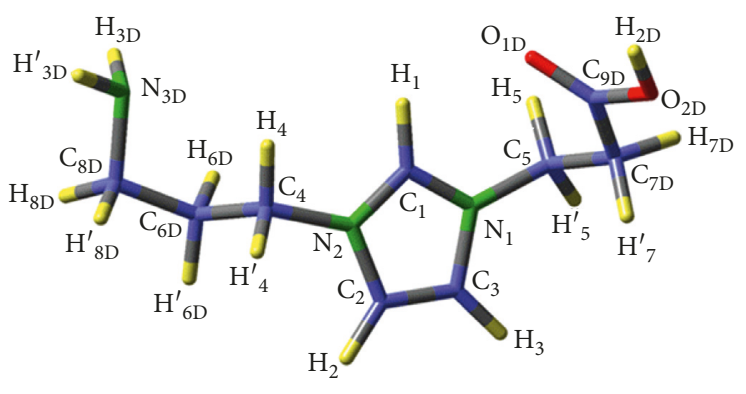

(d)

Scheme 1: Optimized conformers of the synthesized imidazole molecules with their labeled and numbered atoms: (a) 1,3-bis(2-hydroxyethyl) imidazolidinium bromide, (b) 3-(2-ethoxy-2-oxoethly)-1-(3-aminopropyl)-1H-imidazol-3-ium bromide, (c) 1,3-bis(2-carboxyethyl)-4methyl-1H-imidazol-3-ium bromide, and (d) 3-(2-carboxyethyl)-1-(3-aminopropyl)-1H-imidazol-3-ium bromide.

TABLE 1: Some selected geometrical parameters of the common properties of the investigated molecules.

\begin{tabular}{|c|c|c|c|c|c|}
\hline & $L_{\mathrm{A}}$ & $L_{\mathrm{B}}$ & $L_{\mathrm{C}}$ & $L_{\mathrm{D}}$ & $L$ \\
\hline \multicolumn{6}{|c|}{ Selected bond lengths $(\AA)$} \\
\hline $\mathrm{C}_{1}-\mathrm{H}_{1}$ & 1.102 & 1.043 & 1.061 & 1.095 & 0.976 \\
\hline $\mathrm{C}_{1}-\mathrm{N}_{1}$ & 1.295 & 1.301 & - & - & $1.312(7)$ \\
\hline $\mathrm{C}_{3}-\mathrm{N}_{1}$ & 1.403 & 1.398 & 1.335 & 1.396 & $1.374(8)$ \\
\hline $\mathrm{C}_{2}-\mathrm{C}_{3}$ & 1.297 & 1.332 & 1.366 & 1.314 & $1.312(10)$ \\
\hline $\mathrm{C}_{4}-\mathrm{N}_{2}$ & 1.464 & 1.437 & 1.418 & 1.523 & $1.444(8)$ \\
\hline $\mathrm{N}_{1}-\mathrm{C}_{5}$ & 1.464 & 1.474 & 1.429 & 1.505 & $1.444(8)$ \\
\hline $\mathrm{C}_{7 \mathrm{~B}}-\mathrm{O}_{1 \mathrm{~B}}$ & - & 1.204 & - & - & $1.241(8)$ \\
\hline $\mathrm{N}_{3 \mathrm{~B}(\mathrm{D})}-\mathrm{H}_{3 \mathrm{~B}(\mathrm{D})}$ & - & 1.015 & - & 1.013 & 1.010 \\
\hline \multicolumn{6}{|c|}{ Selected bond angles $\left({ }^{\circ}\right)$} \\
\hline $\mathrm{N}_{1}-\mathrm{C}_{1}-\mathrm{N}_{2}$ & 108.7 & 112.6 & 111.7 & 108.9 & $109.2(6)$ \\
\hline $\mathrm{C}_{1}-\mathrm{N}_{1}-\mathrm{C}_{3}$ & 108.9 & 105.7 & 108.9 & 108.6 & $107.9(5)$ \\
\hline $\mathrm{C}_{1}-\mathrm{N}_{1}-\mathrm{C}_{5}$ & 125.1 & 127.6 & 126.0 & 126.0 & $126.2(5)$ \\
\hline $\mathrm{C}_{4}-\mathrm{N}_{2}-\mathrm{C}_{1}$ & 125.1 & 126.5 & 126.9 & 125.2 & $126.2(5)$ \\
\hline $\mathrm{H}_{2}-\mathrm{C}_{2}-\mathrm{N}_{2}$ & 122.6 & 121.8 & 121.8 & 122.3 & 123.4 \\
\hline $\mathrm{C}_{3}-\mathrm{C}_{2}-\mathrm{H}_{2}$ & 130.6 & 129.4 & 129.9 & 130.5 & 128.2 \\
\hline \multicolumn{6}{|c|}{ Selected dihedral angles $\left({ }^{\circ}\right)$} \\
\hline $\mathrm{C}_{4}-\mathrm{N}_{2}-\mathrm{C}_{1}-\mathrm{N}_{1}$ & 177.5 & 179.2 & 179.6 & 178.6 & $178.4(5)$ \\
\hline $\mathrm{N}_{2}-\mathrm{C}_{2}-\mathrm{C}_{3}-\mathrm{N}_{1}$ & 0.2 & 0.4 & 0.3 & 0.1 & $0.9(8)$ \\
\hline $\mathrm{C}_{5}-\mathrm{N}_{1}-\mathrm{C}_{1}-\mathrm{N}_{2}$ & 177.5 & 175.1 & 179.1 & 179.6 & $178.4(5)$ \\
\hline $\mathrm{C}_{5}-\mathrm{N}_{1}-\mathrm{C}_{3}-\mathrm{C}_{2}$ & 177.7 & 175.2 & 179.8 & 179.7 & $177.9(6)$ \\
\hline
\end{tabular}

The data of the molecule showed by $L$ in the last column reflect the X-ray diffraction measurements and calculated values on 1,3-bis(acetamide)imidazol-3ium bromide as given in [22]. The numbers in the paranthesis indicates the experimental error margins on the specific measurements. The labeled and numbered atoms in the first column are presented for each molecule in Scheme 1.

dissolved was dimethyl sulfoxide (DMSO) which did not show any inhibition effect on the bacteria. The pure $L_{\mathrm{A}}, L_{\mathrm{B}}, L_{\mathrm{C}}$, and $L_{\mathrm{D}}$ solutions and the pure microorganism planted mediums were used as the sterility and the growth controls, respectively. The six different concentrations of the each compound were applied to the cells starting from $32 \mu \mathrm{m}$ and diluting to half each time. Each of the 96 microplates was planted in $150 \mu \mathrm{l}$ of Tryptic Soy Broth medium, $30 \mu \mathrm{l}$ of the 
TABLE 2: Proton and carbon nuclear magnetic resonance spectral data of the molecules.

\begin{tabular}{|c|c|c|c|c|c|}
\hline \multirow[t]{2}{*}{ Assignment } & \multicolumn{2}{|c|}{$\begin{array}{l}\text { Proton chemical shift } \\
\text { (ppm) }\end{array}$} & \multirow[t]{2}{*}{ Assignment } & \multicolumn{2}{|c|}{$\begin{array}{l}\text { Carbon chemical shift } \\
(\text { ppm })\end{array}$} \\
\hline & Experimental & Theory & & Experimental & Theory \\
\hline \multicolumn{6}{|c|}{ 1,3-Bis(2-hydroxyethyl) imidazolidinium bromide $\left(L_{\mathrm{A}}\right)$} \\
\hline$s, 1 \mathrm{H}, \mathrm{NCHN}$ & 9.06 & 9.06 & $\mathrm{NCHN}$ & 136.33 & 137.66 \\
\hline$d, 2 \mathrm{H}, \mathrm{HC}=\mathrm{CH}$ & 7.70 & 7.32 & $\mathrm{HC}=\mathrm{CH}$ & 122.60 & 123.06 \\
\hline$t, 4 \mathrm{H}, \mathrm{N}-\mathrm{CH}_{2}$ & 3.93 & 4.01 & $\mathrm{O}-\mathrm{CH}_{2}$ & 59.75 & 61.68 \\
\hline$t, 4 \mathrm{H}, \mathrm{O}-\mathrm{CH}_{2}$ & 3.82 & 3.87 & $\mathrm{~N}-\mathrm{CH}_{2}$ & 51.98 & 52.59 \\
\hline s. $2 \mathrm{H}, \mathrm{OH}$ & - & 1.73 & - & - & - \\
\hline \multicolumn{6}{|c|}{ 3-(2-Ethoxy-2-oxoethly)-1-(3-aminopropyl)-1H-imidazol-3-ium bromide $\left(L_{\mathrm{B}}\right)$} \\
\hline$s, 1 \mathrm{H}, \mathrm{NCHN}$ & 7.79 & 7.73 & $\mathrm{CO}$ & 171.85 & 172.23 \\
\hline$d, 1 \mathrm{H}, \mathrm{HC}=\mathrm{CH}$ & 7.25 & 7.23 & $\mathrm{NCHN}$ & 136.78 & 137.10 \\
\hline$d, 1 \mathrm{H}, \mathrm{HC}=\mathrm{CH}$ & 7.02 & 7.00 & $\mathrm{HC}=\mathrm{CH}$ & 125.13 & 124.74 \\
\hline$s, 2 \mathrm{H}, \mathrm{N}-\mathrm{CH}_{2} \mathrm{CO}$ & 4.23 & $4.22(2)$ & $\mathrm{HC}=\mathrm{CH}$ & 120.73 & 121.34 \\
\hline$q, 2 \mathrm{H}, \mathrm{CH}_{2}-\mathrm{CH}_{3}$ & 3.23 & $3.21(3)$ & $\mathrm{O}-\mathrm{CH}_{2}-\mathrm{CH}_{3}$ & 60.78 & 57.36 \\
\hline$t, 2 \mathrm{H}, \mathrm{N}-\overline{\mathrm{C}} \underline{\mathrm{H}}_{2}-\mathrm{C}$ & 2.95 & $2.96(3)$ & $\overline{\mathrm{N}}-\mathrm{CH}_{2}$ & 54.97 & 54.10 \\
\hline$t, 2 \mathrm{H}, \mathrm{NH}_{2}-\underline{\mathrm{CH}}_{2}$ & 2.55 & $2.54(2)$ & $\mathrm{N}-\mathrm{CH}_{2}-\mathrm{CH}_{2}-$ & 44.97 & 38.64 \\
\hline$m, 2 \mathrm{H}, \mathrm{C}-\underline{\mathrm{CH}}_{2}-\mathrm{C}$ & 2.20 & $2.18(2)$ & $\mathrm{NH}_{2}-\mathrm{CH}_{2-}^{-}$ & 36.84 & 36.61 \\
\hline$t, 3 \mathrm{H}, \mathrm{CH}_{3}$ & 2.02 & $2.04(3)$ & $\mathrm{C}-\mathrm{CH}_{2}-\mathrm{C}$ & 28.72 & 31.52 \\
\hline $\mathrm{NH}_{2}$ & - & $0.5(3)$ & $\overline{\mathrm{C}} \mathrm{H}_{3}$ & 13.64 & 17.70 \\
\hline \multicolumn{6}{|c|}{ 1,3-Bis(2-carboxyethyl)-4-methyl-1H-imidazol-3-ium bromide $\left(L_{\mathrm{C}}\right)$} \\
\hline$s, 1 \mathrm{H}, \mathrm{NCHN}$ & 8.84 & 8.83 & $\mathrm{COOH}$ & 173.03 & $170.3(1)$ \\
\hline$s, 1 \mathrm{H}, \underline{\mathrm{HC}}=\mathrm{C}-\mathrm{CH}_{3}$ & 7.33 & 7.34 & $\mathrm{NCHN}$ & 133.30 & 132.96 \\
\hline$s, \mathrm{OH}^{-}$ & - & $5.95(2)$ & $\underline{\mathrm{C}}-\mathrm{CH}_{3}$ & 129.94 & 130.93 \\
\hline$t, 4 \mathrm{H}, \mathrm{N}-\mathrm{CH} 2$ & 3.64 & $3.62(5)$ & $\underline{\mathrm{C}}=\mathrm{C}-\mathrm{CH}_{3}$ & 116.01 & 119.67 \\
\hline$t, 4 \mathrm{H}, \mathrm{N}-\mathrm{CH} 2$ & 3.64 & $3.62(5)$ & $\mathrm{N}-\mathrm{CH}_{2}$ & 37.53 & $39.7(9)$ \\
\hline$t, 4 \mathrm{H}, \mathrm{CH}_{2}-\mathrm{COOH}$ & 2.91 & $3.10(2)$ & $\mathrm{CH}_{2}-\mathrm{COOH}$ & 26.79 & $33.8(5)$ \\
\hline$s, 3 \mathrm{H},-\overline{\mathrm{CH}} 3$ & 2.38 & 2.37 & $\mathrm{CH}_{3}$ & 9.01 & 10.26 \\
\hline \multicolumn{6}{|c|}{ 3-(2-Carboxyethyl)-1-(3-aminopropyl)-1H-imidazol-3-ium bromide $\left(L_{\mathrm{D}}\right)$} \\
\hline$s, 1 \mathrm{H}, \mathrm{NCHN}$ & 9.11 & 9.11 & $\mathrm{COOH}$ & 170.21 & 177.74 \\
\hline$d, 1 \mathrm{H}, \mathrm{HC}=\mathrm{CH}$ & 7.72 & 7.71 & $\mathrm{NCHN}$ & 137.16 & 137.47 \\
\hline$d, 1 \mathrm{H}, \mathrm{HC}=\mathrm{CH}$ & 7.65 & 7.63 & $\mathrm{HC}=\mathrm{CH}$ & 123.94 & 124.97 \\
\hline$s, \mathrm{OH}$ & - & 6.39 & $\mathrm{HC}=\mathrm{CH}$ & 121.50 & 124.69 \\
\hline$t, 4 \mathrm{H}, \mathrm{N}-\mathrm{CH}_{2}$ & 4.45 & $4.47(1)$ & $\mathrm{N}-\mathrm{CH}_{2}$ & 60.01 & 60.29 \\
\hline$t, 2 \mathrm{H}, \mathrm{COOH}-\mathrm{C}$ & 3.33 & 3.34 & $\mathrm{~N}-\mathrm{CH}_{2}$ & 52.02 & 53.30 \\
\hline$t, 2 \mathrm{H}, \mathrm{NH}_{2}-\mathrm{CH}_{2}$ & 3.05 & 3.03 & $\mathrm{NH}_{2}-\mathrm{CH}_{2}$ & 45.42 & 45.41 \\
\hline$m, 2 \mathrm{H}, \mathrm{C}-\mathrm{CH}_{2}-\mathrm{C}$ & 2.33 & 2.31 & $\mathrm{C}-\underline{\mathrm{CH}_{2}}-\mathrm{C}$ & 36.18 & 40.05 \\
\hline $\mathrm{NH}_{2}$ & - & $0.7(3)$ & $\mathrm{COO} H-\mathrm{CH}_{2}$ & 27.76 & 34.43 \\
\hline
\end{tabular}

bacteria or the yeast culture, and $20 \mu \mathrm{l}$ of the chemical compound solution. All microplates were incubated at $37^{\circ} \mathrm{C}$ for $24 \mathrm{hr}$. The absorbance was measured at $600 \mathrm{~nm}$.

2.3.2. Cytotoxicity. 3-(4,5-Dimethylthiazol-2-yl)-2,5-diphenyl tetrazolium bromide (MTT) assay was used to observe the cytotoxicity of synthesized compounds on human cervical cancer cell line (HeLa), human liver cancer cell line (Hep G2), and healthy mouse embryonic fibroblast cell line (MEF). All cell lines were provided with American Type Culture Collection (ATCC, Manassas, VA, USA). A certain population of the cells were incubated in Dulbecco's modified Eagle's Medium (DMEM) provided with Life Technologies GIBCO, Grand Island, NY, USA involving 1\% penicillin streptomycin and 1\% L-glutamine and HAMS F12 $(1: 1)$ broth medium at $37^{\circ} \mathrm{C}$ under $5 \% \mathrm{CO}_{2}$. The cells were planted in 96-multiwell plates with approximately equal numbers of $10^{5}$, and they were allowed further incubation for $24 \mathrm{hr}$. The seven different doses of each compound were applied to the cancer cell lines and the MEF cells. The applied doses were $400 \mu \mathrm{m}, 200 \mu \mathrm{m}, 100 \mu \mathrm{m}, 50 \mu \mathrm{m}, 25 \mu \mathrm{m}, 12.5 \mu \mathrm{m}$, and $6.25 \mu \mathrm{m}$, and the dose application time was $24 \mathrm{hr}$. The surviving control for each cell was carried out against the cells not exposed to any dose. Then, $20 \mu \mathrm{l} /$ plate of $5 \mathrm{mg} / \mathrm{ml}$ MTT solution was added into the each well and left to further incubation between 2 and $4 \mathrm{hr}$. The excess MTT solutions were removed from the wells, and $200 \mu$ l of ultra-pure DMSO was added. The set was left in dark for 5 min before measuring the color intensities on a $492 \mathrm{~nm}$ spectrophotometer.

2.4. Computational Modeling. All calculations were carried out in the framework of Gaussian 09 package. The molecules were optimized in their ground state using Becke3-LeeYang-Parr (B3LYP) exchange correlation functional method and 6-311G+(2d, p) basis set within density functional theory (DFT). Then, the NMR spectra and the IR spectra were calculated on the optimized geometries using the same method and the same basis set. The gaugeindependent atomic orbital (GIAO) method was adopted to acquire theoretical ${ }^{1} \mathrm{H}$ and ${ }^{13} \mathrm{C}$ NMR shifts, which were 


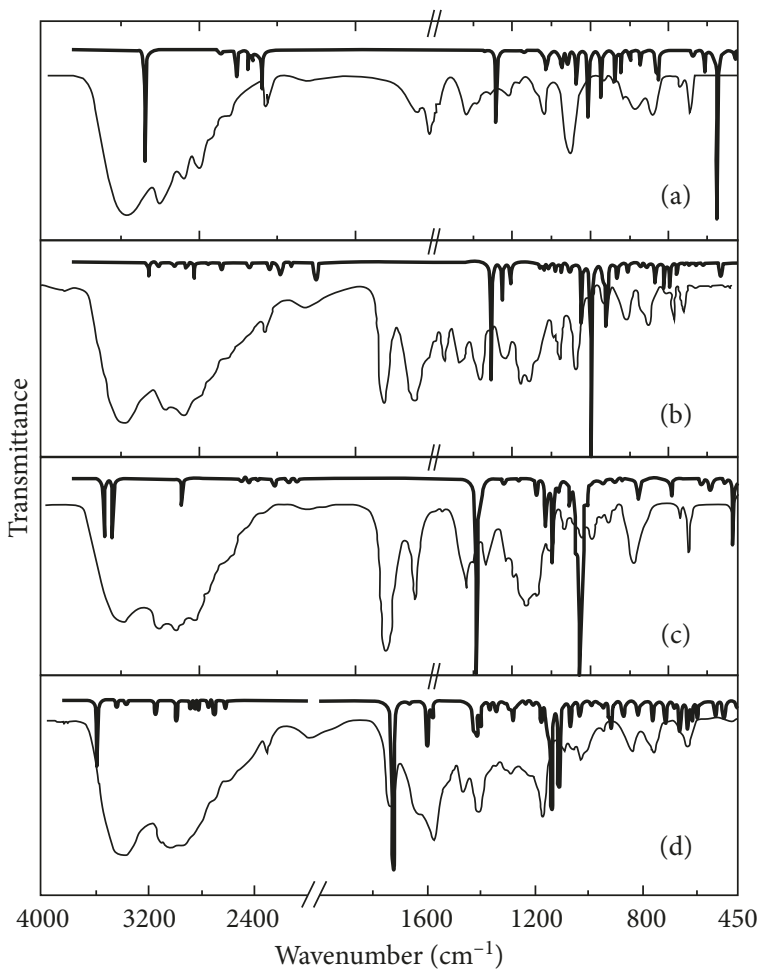

FIgURE 1: Calculated (bold lines) and experimental (pale lines) infrared spectra of the synthesized imidazole molecules: (a) 1,3bis(2-hydroxyethyl) imidazolidinium bromide, (b) 3-(2-ethoxy2-oxoethly)-1-(3-aminopropyl)-1H-imidazol-3-ium bromide, (c) 1,3-bis(2-carboxyethyl)-4-methyl-1H-imidazol-3-ium bromide, and (d) 3-(2-carboxyethyl)-1-(3-aminopropyl)-1H-imidazol-3-ium bromide.

converted to that of tetramethylsilane scale. The IR spectra were scaled by the factor 0.9613 due to the theoretical miscalculations [19-21]. The vibrational modes were assigned by observing the animation property of the frequency calculations provided with Gaussian 09 package.

\section{Result and Discussion}

NMR and IR spectra are reliable methods to elucidate an organic material or some of metal complexes. They can also be used to verify calculated molecular structure by comparing calculated spectra with corresponding experimental spectra and thus determining structural parameters and complete description of chemicals investigated.

3.1. Molecular Structures. The NMR measurements were taken in dilute $\mathrm{D}_{2} \mathrm{O}$ solution, while the IR spectra were recorded in the solid $\mathrm{KBr}$ pellet. Therefore, NMR and infrared spectra may reflect different molecular structures as the molecule surrounded by $\mathrm{D}_{2} \mathrm{O}$ molecules in NMR spectra while the intermolecular interactions exist in the IR spectra, especially on - $\mathrm{CH}$ and - $\mathrm{OH}$ bonds [22]. On the theoretical calculation side, the crystalline phase calculations were excluded due to the single crystal form of the molecules obtained for X-ray analysis. The gas phase calculations were adopted considering differences with other phases with $2 \%$ maximum error margin which were especially on the $-\mathrm{CH}$ and $-\mathrm{OH}$ bond lengths.

The process of the theoretical modeling of the molecules has initially been realized by using the potential energy surface scanning method for the selected dihedral angles of each molecule, thus obtaining the lowest energy conformers in the gas phase, and the resulting optimized conformers are given in Scheme 1. The imidazole rings except that of $L_{C}$ with its $\mathrm{CH}_{3}$ attachment and the $\mathrm{CH}_{2}$ groups directly bonded to the nitrogen of the rings are common in the all molecules.

$L_{\mathrm{A}}$ has the point group symmetry C2 as the other molecules were found to have $\mathrm{C} 1$ symmetry. The lower point group symmetry of the $L_{\mathrm{B}}, L_{\mathrm{C}}$, and $L_{\mathrm{D}}$ in comparison with the C2 symmetry of $L_{\mathrm{A}}$ is because of the attachment of the different aliphatic chains to their imidazole rings. The calculated optimized energies and the dipole moments of $L_{\mathrm{A}}, L_{\mathrm{D}}, L_{\mathrm{B}}$, and $L_{\mathrm{C}}$ are, respectively, $-534.4,-667.3,-706.6$, and -800.5 in units of a.u. and 2.11, 3.41, 4.54, and 7.78 in units of Debye.

The calculated parameters of the common properties of the molecules are presented in Table 1. Although the molecules differ from each other by their moieties bonded to the imidazole rings, the bond lengths, the bond angles, and the dihedral angles belong to the ring, and its immediate vicinity are in good agreement with each other and with the corresponding X-ray diffractometer (XRD) results of previously investigated similar molecule 1,3-bis(acetamide) imidazol-3-ium bromide which was crystallized successfully [22]. The dihedral angles chosen on the imidazole ring are either about $0^{\circ}$ or $180^{\circ}$, implying the aromatic structure as expected. The $\mathrm{C}-\mathrm{N}$ bond lengths which bind the rings and the aliphatic moieties, that is, $\mathrm{C}_{4}-\mathrm{N}_{2}$ and $\mathrm{N}_{1}-\mathrm{C}_{5}$ are equal in $L_{\mathrm{A}}$ reflecting the symmetric structure of the molecule. However, these are different in $L_{\mathrm{B}}, L_{\mathrm{C}}$, and $L_{\mathrm{D}}$ because of the different moieties on the both side of their aromatic rings. Although the symmetry of $L_{\mathrm{C}}$ was broken by the $\mathrm{C}-\mathrm{CH}_{3}$ group instead of $\mathrm{C}-\mathrm{H}$ in the ring, no drastic changes were observed in the concerning ring parameters. It can be inferred that the common geometrical parameters are consistent with each other with a priori theoretical confirmations before NMR and IR spectra clarifications of the calculated molecular structures.

3.2. Nuclear Magnetic Resonance Spectra. The experimental and theoretical chemical shifts of ${ }^{1} \mathrm{H}$ NMR and ${ }^{13} \mathrm{C}$ NMR spectra of $L_{\mathrm{A}}, L_{\mathrm{B}}, L_{\mathrm{C}}$, and $L_{\mathrm{D}}$ molecules are given in Table 2. The calculations were carried out in the gas phase considering their optimized geometries given in Scheme 1. The proton signals for $-\mathrm{NH}_{2}$ and $-\mathrm{OH}$ in all were absent in the experimental ${ }^{1} \mathrm{H}$ NMR spectra because the solvent was $\mathrm{D}_{2} \mathrm{O}$ concerning the solubility of the specimens which exchanged $\mathrm{NH}_{2}$ and $\mathrm{OH}$ protons with deuterium. Although their detailed analysis left to the IR spectra in the following section, the calculated shifts $\delta 1.73 \mathrm{ppm}$ of $\mathrm{OH}$ in $L_{\mathrm{A}}$ and $\delta 0.5 \mathrm{ppm}$ and $\delta 0.7 \mathrm{ppm}$ of $\mathrm{NH}_{2}$ in $L_{\mathrm{B}}$ and $L_{\mathrm{D}}$, respectively, are in the typical chemical shift range of $\mathrm{R}-\mathrm{NH}_{2}$ and $\mathrm{R}-\mathrm{OH}$ groups.

The imidazole proton $\left(\mathrm{NCHN}, \mathrm{H}_{1}\right)$ shifts of $L_{\mathrm{A}}, L_{\mathrm{C}}$, and $L_{\mathrm{D}}$ with $9.06 \mathrm{ppm}, 8.84 \mathrm{ppm}$, and $9.11 \mathrm{ppm}$, respectively, are noticeably bigger than that of $L_{\mathrm{B}}$ with $7.79 \mathrm{ppm}$. That can be due to the intramolecular interactions of the $\mathrm{NCHN}$ 
TABLE 3: The experimental and theoretical vibrational wave numbers for the infrared spectra of 1,3-bis(2-hydroxyethyl) imidazolidinium bromide $\left(L_{\mathrm{A}}\right)$ with its symbolled and numbered atoms in Figure 1(a).

\begin{tabular}{|c|c|c|}
\hline Vibrational assignments/vibrating atoms & Theory & Experiment \\
\hline$v_{\mathrm{s}}(\mathrm{OH}) /\left(\mathrm{O}_{1 \mathrm{~A}}-\mathrm{H}_{1 \mathrm{~A}}, \mathrm{H}_{2 \mathrm{~A}}-\mathrm{O}_{2 \mathrm{~A}}\right)$ & 3477 & \multirow{2}{*}{3358} \\
\hline$v_{\mathrm{as}}(\mathrm{OH}) /\left(\mathrm{O}_{1 \mathrm{~A}}-\mathrm{H}_{1 \mathrm{~A}}, \mathrm{H}_{2 \mathrm{~A}}-\mathrm{O}_{2 \mathrm{~A}}\right)$ & 3477 & \\
\hline$v_{\mathrm{as}}\left(\mathrm{CH}_{2}\right) /\left(\mathrm{C}_{4}-\mathrm{H}_{4}, \mathrm{H}_{4}^{\prime}-\mathrm{C}_{4}\right),\left(\mathrm{C}_{5}-\mathrm{H}_{5}, \mathrm{H}^{\prime}{ }_{5}-\mathrm{C}_{5}\right)$ & 3093 & \multirow{6}{*}{$3114-2822$} \\
\hline$v_{\mathrm{as}}\left(\mathrm{CH}_{2}\right) /\left(\mathrm{C}_{6 \mathrm{~A}}-\mathrm{H}_{6 \mathrm{~A}}, \mathrm{H}_{6 \mathrm{~A}}^{\prime}-\mathrm{C}_{6 \mathrm{~A}}\right),\left(\mathrm{C}_{7 \mathrm{~A}}-\mathrm{H}_{7 \mathrm{~A}}, \mathrm{H}^{\prime}{ }_{7 \mathrm{~A}}-\mathrm{C}_{7 \mathrm{~A}}\right)$ & 3011 & \\
\hline$\nu(\mathrm{NCHN}) /\left(\mathrm{C}_{1}-\mathrm{H}_{1}\right)$ & 2949 & \\
\hline$v_{\mathrm{s}}(\mathrm{CH}) /\left(\mathrm{C}_{2}-\mathrm{H}_{2}, \mathrm{H}_{3}-\mathrm{C}_{3}\right)$ & 2928 & \\
\hline$v_{\mathrm{s}}\left(\mathrm{CH}_{2}\right) /\left(\mathrm{C}_{4}-\mathrm{H}_{4}, \mathrm{H}^{\prime}{ }_{4}-\mathrm{C}_{4}\right),\left(\mathrm{C}_{5}-\mathrm{H}_{5}, \mathrm{H}^{\prime}{ }_{5}-\mathrm{C}_{5}\right)$ & 2914 & \\
\hline$v_{\mathrm{as}}(\mathrm{CH}) /\left(\mathrm{C}_{2}-\mathrm{H}_{2}, \mathrm{H}_{3}-\mathrm{C}_{3}\right)$ & 2899 & \\
\hline$v_{\mathrm{s}}\left(\mathrm{CH}_{2}\right) /\left(\mathrm{C}_{6 \mathrm{~A}}-\mathrm{H}_{6 \mathrm{~A}}, \mathrm{H}^{\prime}{ }_{6 \mathrm{~A}}-\mathrm{C}_{6 \mathrm{~A}}\right),\left(\mathrm{C}_{7 \mathrm{~A}}-\mathrm{H}_{7 \mathrm{~A}}, \mathrm{H}^{\prime}{ }_{7 \mathrm{~A}}-\mathrm{C}_{7 \mathrm{~A}}\right)$ & 2880 & 2808 \\
\hline$\nu_{\mathrm{as}}(\mathrm{CN}) /\left(\mathrm{C}_{1}-\mathrm{N}_{1}, \mathrm{~N}_{2}-\mathrm{C}_{1}\right)$ & 1682 & 1630 \\
\hline$v_{\mathrm{s}}(\mathrm{CN}) /\left(\mathrm{C}_{1}-\mathrm{N}_{1}, \mathrm{~N}_{2}-\mathrm{C}_{1}\right)$ & 1543 & 1592 \\
\hline$\delta_{\mathrm{sc}}\left(\mathrm{CH}_{2}\right) /\left(\mathrm{C}_{6 \mathrm{~A}}-\mathrm{H}_{6 \mathrm{~A}}, \mathrm{H}_{6 \mathrm{~A}}^{\prime}-\mathrm{C}_{6 \mathrm{~A}}\right),\left(\mathrm{C}_{7 \mathrm{~A}}-\mathrm{H}_{7 \mathrm{~A}}, \mathrm{H}^{\prime}{ }_{7 \mathrm{~A}}-\mathrm{C}_{7 \mathrm{~A}}\right)$ & 1452 & \multirow{3}{*}{1463} \\
\hline$\delta_{\mathrm{sc}}\left(\mathrm{CH}_{2}\right) /\left(\mathrm{C}_{4}-\mathrm{H}_{4}, \mathrm{H}^{\prime}{ }_{4}-\mathrm{C}_{4}\right),\left(\mathrm{C}_{5}-\mathrm{H}_{5}, \mathrm{H}^{\prime}{ }_{5}-\mathrm{C}_{5}\right)$ & 1428 & \\
\hline$\delta(\mathrm{OH}) /\left(\mathrm{O}_{1 \mathrm{~A}}-\mathrm{H}_{1 \mathrm{~A}}\right),\left(\mathrm{O}_{2 \mathrm{~A}}-\mathrm{H}_{2 \mathrm{~A}}\right)$ & 1411 & \\
\hline$\gamma_{\mathrm{t}}\left(\mathrm{CH}_{2}\right)+\delta_{\mathrm{r}}(\mathrm{CH})+\delta(\mathrm{NCHN}) /\left(\mathrm{C}_{4}-\mathrm{H}_{4}, \mathrm{H}_{4}^{\prime}-\mathrm{C}_{4}\right),\left(\mathrm{C}_{2}-\mathrm{H}_{2}, \mathrm{C}_{3}-\mathrm{H}_{3}\right),\left(\mathrm{C}_{1}-\mathrm{H}_{1}\right)$ & 1375 & 1373 \\
\hline$\gamma_{\mathrm{w}}\left(\mathrm{CH}_{2}\right)+\nu_{\mathrm{s}}(\mathrm{CN}) /\left(\mathrm{C}_{5}-\mathrm{H}_{5}, \mathrm{H}^{\prime}{ }_{5}-\mathrm{C}_{5}\right),\left(\mathrm{C}_{7 \mathrm{~A}}-\mathrm{H}_{7 \mathrm{~A}}, \mathrm{H}^{\prime}{ }_{7 \mathrm{~A}}-\mathrm{C}_{7 \mathrm{~A}}\right),\left(\mathrm{C}_{4}-\mathrm{N}_{2}, \mathrm{~N}_{1}-\mathrm{C}_{5}\right)$ & 1355 & \multirow{2}{*}{1330} \\
\hline$\delta_{\mathrm{r}}(\mathrm{CH}) /\left(\mathrm{C}_{2}-\mathrm{H}_{2}, \mathrm{H}_{3}-\mathrm{C}_{3}\right)$ & 1345 & \\
\hline$\gamma_{\mathrm{t}}\left(\mathrm{CH}_{2}\right)+\delta(\mathrm{NCHN})+\delta_{\mathrm{r}}(\mathrm{CH}) /\left(\mathrm{C}_{6 \mathrm{~A}}-\mathrm{H}_{6 \mathrm{~A}}, \mathrm{H}^{\prime}{ }_{6 \mathrm{~A}}-\mathrm{C}_{6 \mathrm{~A}}\right),\left(\mathrm{C}_{1}-\mathrm{H}_{1}\right),\left(\mathrm{C}_{2}-\mathrm{H}_{2}, \mathrm{H}_{3}-\mathrm{C}_{3}\right)$ & 1323 & \multirow{3}{*}{1301} \\
\hline$\gamma_{\mathrm{t}}\left(\mathrm{CH}_{2}\right)+\delta(\mathrm{NCHN})+\delta_{\mathrm{r}}(\mathrm{CH}) /\left(\mathrm{C}_{4}-\mathrm{H}_{4}, \mathrm{H}^{\prime}{ }_{4}-\mathrm{C}_{4}\right),\left(\mathrm{C}_{1}-\mathrm{H}_{1}\right),\left(\mathrm{C}_{2}-\mathrm{H}_{2}, \mathrm{H}_{3}-\mathrm{C}_{3}\right)$ & 1313 & \\
\hline$\delta(\mathrm{NCHN})+\gamma_{\mathrm{w}}(\mathrm{OH}) /\left(\mathrm{C}_{1}-\mathrm{H}_{1}\right),\left(\mathrm{O}_{1 \mathrm{~A}}-\mathrm{H}_{1 \mathrm{~A}}, \mathrm{H}_{2 \mathrm{~A}}-\mathrm{O}_{2 \mathrm{~A}}\right)$ & 1274 & \\
\hline$\gamma_{\mathrm{t}}\left(\mathrm{CH}_{2}\right)+\delta_{\mathrm{r}}(\mathrm{OH}) /\left(\mathrm{C}_{4}-\mathrm{H}_{4}, \mathrm{H}^{\prime}{ }_{4}-\mathrm{C}_{4}\right),\left(\mathrm{C}_{5}-\mathrm{H}_{5}, \mathrm{H}^{\prime}{ }_{5}-\mathrm{C}_{5}\right),\left(\mathrm{O}_{1 \mathrm{~A}}-\mathrm{H}_{1 \mathrm{~A}}, \mathrm{O}_{2 \mathrm{~A}}-\mathrm{H}_{2 \mathrm{~A}}\right)$ & 1212 & \multirow[t]{2}{*}{1265} \\
\hline$\gamma_{\mathrm{t}}\left(\mathrm{CH}_{2}\right)+\delta_{\mathrm{r}}(\mathrm{OH}) /\left(\mathrm{C}_{6 \mathrm{~A}}-\mathrm{H}_{6 \mathrm{~A}}, \mathrm{H}_{6 \mathrm{~A}}^{\prime}-\mathrm{C}_{6 \mathrm{~A}}\right),\left(\mathrm{C}_{7 \mathrm{~A}}-\mathrm{H}_{7 \mathrm{~A}}, \mathrm{H}^{\prime}{ }_{7 \mathrm{~A}}-\mathrm{C}_{7 \mathrm{~A}}\right),\left(\mathrm{O}_{1 \mathrm{~A}}-\mathrm{H}_{1 \mathrm{~A}}, \mathrm{O}_{2 \mathrm{~A}}-\mathrm{H}_{2 \mathrm{~A}}\right)$ & 1209 & \\
\hline$\delta_{\mathrm{sc}}(\mathrm{CH}) /\left(\mathrm{C}_{2}-\mathrm{H}_{2}, \mathrm{H}_{3}-\mathrm{C}_{3}\right)$ & 1149 & \multirow{2}{*}{1179} \\
\hline$v_{\mathrm{as}}(\mathrm{CN}) /\left(\mathrm{C}_{3}-\mathrm{N}_{1}, \mathrm{~N}_{2}-\mathrm{C}_{2}\right)+\left(\mathrm{C}_{4}-\mathrm{N}_{2}, \mathrm{~N}_{1}-\mathrm{C}_{5}\right)$ & 1143 & \\
\hline$v_{\mathrm{as}}(\mathrm{CO})+v_{\mathrm{as}}(\mathrm{CC}) /\left(\mathrm{C}_{6 \mathrm{~A}}-\mathrm{O}_{2 \mathrm{~A}}, \mathrm{O}_{1 \mathrm{~A}}-\mathrm{C}_{7 \mathrm{~A}}\right),\left(\mathrm{C}_{6 \mathrm{~A}}-\mathrm{C}_{4}, \mathrm{C}_{5}-\mathrm{C}_{7 \mathrm{~A}}\right)$ & 1077 & \multirow{3}{*}{1080} \\
\hline$v_{\mathrm{s}}(\mathrm{CO})+v_{\mathrm{s}}(\mathrm{CC}) /\left(\mathrm{C}_{6 \mathrm{~A}}-\mathrm{O}_{2 \mathrm{~A}}, \mathrm{O}_{1 \mathrm{~A}}-\mathrm{C}_{7 \mathrm{~A}}\right),\left(\mathrm{C}_{6 \mathrm{~A}}-\mathrm{C}_{4}, \mathrm{C}_{5}-\mathrm{C}_{7 \mathrm{~A}}\right)$ & 1076 & \\
\hline$\delta_{\mathrm{r}}\left(\mathrm{CH}_{2}\right)+v_{\mathrm{s}}(\mathrm{CO}) /\left(\mathrm{C}_{4}-\mathrm{H}_{4}, \mathrm{H}^{\prime}{ }_{4}-\mathrm{C}_{4}\right),\left(\mathrm{C}_{5}-\mathrm{H}_{5}, \mathrm{H}^{\prime}{ }^{-}-\mathrm{C}_{5}\right),\left(\mathrm{C}_{6 \mathrm{~A}}-\mathrm{O}_{2 \mathrm{~A}}, \mathrm{C}_{7 \mathrm{~A}}-\mathrm{O}_{1 \mathrm{~A}}\right)$ & 1047 & \\
\hline$\delta_{\mathrm{r}}\left(\mathrm{CH}_{2}\right)+v_{\mathrm{s}}(\mathrm{CN}) /\left(\mathrm{C}_{6 \mathrm{~A}}-\mathrm{H}_{6 \mathrm{~A}}, \mathrm{H}_{6 \mathrm{~A}}^{\prime}-\mathrm{C}_{6 \mathrm{~A}}\right),\left(\mathrm{C}_{7 \mathrm{~A}}-\mathrm{H}_{7 \mathrm{~A}}, \mathrm{H}_{7 \mathrm{~A}}^{\prime}-\mathrm{C}_{7 \mathrm{~A}}\right),\left(\mathrm{C}_{3}-\mathrm{N}_{1}, \mathrm{~N}_{2}-\mathrm{C}_{2}\right)$ & 997 & \multirow{2}{*}{956} \\
\hline$\gamma(\mathrm{NCHN}) /\left(\mathrm{C}_{1}-\mathrm{H}_{1}\right)$ & 946 & \\
\hline$v_{\mathrm{s}}(\mathrm{CC}) /\left(\mathrm{C}_{6 \mathrm{~A}}-\mathrm{C}_{4}, \mathrm{C}_{5}-\mathrm{C}_{7 \mathrm{~A}}\right)$ & 930 & 917 \\
\hline$\delta_{\mathrm{r}}\left(\mathrm{CH}_{2}\right)+v_{\mathrm{as}}(\mathrm{CO}) /\left(\mathrm{C}_{4}-\mathrm{H}_{4}, \mathrm{H}^{\prime}{ }_{4}-\mathrm{C}_{4}\right),\left(\mathrm{C}_{5}-\mathrm{H}_{5}, \mathrm{H}^{\prime}{ }_{5}-\mathrm{C}_{5}\right),\left(\mathrm{C}_{6 \mathrm{~A}}-\mathrm{O}_{2 \mathrm{~A}}, \mathrm{O}_{1 \mathrm{~A}}-\mathrm{C}_{7 \mathrm{~A}}\right)$ & 867 & \multirow{2}{*}{875} \\
\hline$\delta_{\mathrm{r}}\left(\mathrm{CH}_{2}\right) /\left(\mathrm{C}_{4}-\mathrm{H}_{4}, \mathrm{H}_{4}^{\prime}-\mathrm{C}_{4}\right),\left(\mathrm{C}_{6 \mathrm{~A}}-\mathrm{H}_{6 \mathrm{~A}}, \mathrm{H}_{6 \mathrm{~A}}^{\prime}-\mathrm{C}_{6 \mathrm{~A}}\right)$ & 861 & \\
\hline$\gamma_{\mathrm{w}}(\mathrm{CH})+\gamma(\mathrm{NCHN}) /\left(\mathrm{C}_{2}-\mathrm{H}_{2}, \mathrm{H}_{3}-\mathrm{C}_{3}\right),\left(\mathrm{C}_{1}-\mathrm{H}_{1}\right)$ & 853 & 840 \\
\hline$v_{\mathrm{as}}(\mathrm{CN})+\delta_{\mathrm{r}}\left(\mathrm{CH}_{2}\right) /\left(\mathrm{N}_{2}-\mathrm{C}_{4}, \mathrm{~N}_{1}-\mathrm{C}_{5}\right),\left(\mathrm{C}_{6 \mathrm{~A}}-\mathrm{H}_{6 \mathrm{~A}}, \mathrm{H}_{6 \mathrm{~A}}^{\prime}-\mathrm{C}_{6 \mathrm{~A}}\right),\left(\mathrm{C}_{7 \mathrm{~A}}-\mathrm{H}_{7 \mathrm{~A}}, \mathrm{H}^{\prime}{ }_{7 \mathrm{~A}}-\mathrm{C}_{7 \mathrm{~A}}\right)$ & 677 & 673 \\
\hline$\gamma(\mathrm{NCHN}) /\left(\mathrm{C}_{1}-\mathrm{H}_{1}\right)$ & 617 & 639 \\
\hline
\end{tabular}

$\nu$, stretching; $\delta$, in-plane bending; $\gamma$, out-of-plane bending; s, symmetric; as, asymmetric; sc, scissoring; r, rocking; t, twisting; w, wagging.

hydrogen with the close oxygen atoms since the oxygen reduces the electron density on the hydrogen depending on the distance between them, thus causing higher NMR shifts. Indeed, the $\mathrm{H}_{1}-\mathrm{O}_{1 \mathrm{~A}}$ in $L_{\mathrm{A}}$, the $\mathrm{H}_{1}-\mathrm{O}_{1 \mathrm{C}}$ in $L_{\mathrm{C}}$, and the $\mathrm{H}_{1}-\mathrm{O}_{1 \mathrm{D}}$ in $L_{\mathrm{D}}$ are $2.61 \AA, 2.42 \AA$, and $2.41 \AA$, respectively. These distances which were measured from the theoretical models of the molecules are quite longer than that $2.85 \AA$ distance of the $\mathrm{H}_{1}-\mathrm{O}_{1 \mathrm{~B}}$ measured in $L_{\mathrm{B}}$ which results in small shifts for the $\mathrm{H}_{1}$ of $L_{\mathrm{B}}$. This is supported by the fact that the other imidazole proton shifts of $\mathrm{H}_{2}$ and $\mathrm{H}_{3}$ are all in close values about 7.7 ppm for all molecules as no distinct intermolecular interactions possible on $\mathrm{H}_{2}$ and $\mathrm{H}_{3}$ in any of them. In addition, the NMR signals of $\mathrm{CH}_{2}$ protons in the aliphatic chains of all molecules and the smallest proton shifts of $\mathrm{CH}_{3}$ protons in $L_{\mathrm{B}}$ and $L_{\mathrm{C}}$ molecules are theoretically and experimentally in agreement with the expected NMR results. These NMR data are in accordance with the previous study on a similar imidazole salt $[23,24]$ in which the protons belong to the aliphatic chain found in $4.15 \mathrm{ppm}-2.08 \mathrm{ppm}$, the carbons belong to the imidazole ring, and the aliphatic chain is found in $139.2 \mathrm{ppm}-123 \mathrm{ppm}$ and $62.5 \mathrm{ppm}-$ $33.9 \mathrm{ppm}$ as in this study.

The eight $R$-squared tests using the data in Table 2 provide least $99.8 \%$ agreement between the experimental and the theoretical ${ }^{1} \mathrm{H}$ and ${ }^{13} \mathrm{C}$ NMR for $L_{\mathrm{A}}, L_{\mathrm{B}}, L_{\mathrm{C}}$, and $L_{\mathrm{D}}$. The theoretical results for NMR are in very good agreement with the experimental results as well as the observation of the expected specific values. Thus, one can infer that the calculated atomic configurations of the all molecules are good estimations except the exclusion of the interchangeable hydrogens.

3.3. Infrared Spectra. In Figure 1, the experimental infrared spectra of $L_{\mathrm{A}}, L_{\mathrm{B}}, L_{\mathrm{C}}$, and $L_{\mathrm{D}}$ in the $450-4000 \mathrm{~cm}^{-1}$ region are given against their IR spectra calculations. The detailed account of the IR spectra including the in-plane vibrations of the stretching, scissoring, and rocking and the out-of-plane vibrations of the wagging and twisting for each molecule is presented for $L_{\mathrm{A}}, L_{\mathrm{B}}, L_{\mathrm{C}}$, and $L_{\mathrm{D}}$ in Tables 3-6, respectively. 
TABLE 4: The experimental and theoretical vibrational wave numbers for the infrared spectra of 3-(2-ethoxy-2-oxoethly)-1-(3-aminopropyl)1 H-imidazol-3-ium bromide $\left(L_{\mathrm{B}}\right)$ with its symbolled and numbered atoms in Figure 1(b).

\begin{tabular}{|c|c|c|}
\hline Vibrational assignments/vibrating atoms & Theory & Experiment \\
\hline$\nu(\mathrm{NCHN}) /\left(\mathrm{C}_{1}-\mathrm{H}_{1}\right)$ & 3460 & \multirow{3}{*}{3400} \\
\hline$v_{\mathrm{as}}\left(\mathrm{NH}_{2}\right) /\left(\mathrm{N}_{3 \mathrm{~B}}-\mathrm{H}_{3 \mathrm{~B}}, \mathrm{H}_{3 \mathrm{~B}}^{\prime}-\mathrm{N}_{3 \mathrm{~B}}\right)$ & 3412 & \\
\hline$v_{\mathrm{s}}\left(\mathrm{NH}_{2}\right) /\left(\mathrm{N}_{3 \mathrm{~B}}-\mathrm{H}_{3 \mathrm{~B}}, \mathrm{H}_{3 \mathrm{~B}}^{\prime}-\mathrm{N}_{3 \mathrm{~B}}\right)$ & 3345 & \\
\hline$\nu_{\mathrm{as}}\left(\mathrm{CH}_{2}\right) /\left(\mathrm{C}_{9 \mathrm{~B}}-\mathrm{H}_{9 \mathrm{~B}}, \mathrm{H}_{9 \mathrm{~B}}^{\prime}-\mathrm{C}_{9 \mathrm{~B}}\right)$ & 3327 & \multirow{13}{*}{$3192-2720$} \\
\hline$v_{\mathrm{s}}\left(\mathrm{CH}_{2}\right)+v_{\mathrm{s}}\left(\mathrm{CH}_{2}\right) /\left(\mathrm{C}_{1}-\mathrm{H}_{5}, \mathrm{H}^{\prime}{ }_{5}-\mathrm{C}_{1}\right),\left(\mathrm{C}_{9 \mathrm{~B}}-\mathrm{H}_{9 \mathrm{~B}}, \mathrm{H}_{9 \mathrm{~B}}^{\prime}-\mathrm{C}_{9 \mathrm{~B}}\right)$ & 3270 & \\
\hline$v\left(\mathrm{CH}_{2}\right) /\left(\mathrm{C}_{4}-\mathrm{H}_{4}^{\prime}\right)$ & 3263 & \\
\hline$v\left(\mathrm{CH}_{2}\right) /\left(\mathrm{C}_{8 \mathrm{~B}}-\mathrm{H}_{8 \mathrm{~B}}\right)$ & 3226 & \\
\hline$v_{\mathrm{as}}\left(\mathrm{CH}_{2}\right) /\left(\mathrm{C}_{5}-\mathrm{H}_{5}, \mathrm{H}^{\prime}{ }_{5}-\mathrm{C}_{5}\right)$ & 3221 & \\
\hline$v_{\mathrm{s}}\left(\mathrm{CH}_{2}\right) /\left(\mathrm{C}_{5}-\mathrm{H}_{5}, \mathrm{H}^{\prime}{ }_{5}-\mathrm{C}_{5}\right)$ & 3157 & \\
\hline$\nu(\mathrm{CH}) /\left(\mathrm{C}_{3}-\mathrm{H}_{3}\right)$ & 3087 & \\
\hline$v(\mathrm{CH}) /\left(\mathrm{C}_{2}-\mathrm{H}_{2}\right)$ & 2946 & \\
\hline$v_{\mathrm{as}}\left(\mathrm{CH}_{2}\right) /\left(\mathrm{C}_{6 \mathrm{~B}}-\mathrm{H}_{6 \mathrm{~B}}, \mathrm{H}^{\prime}{ }_{6 \mathrm{~B}}-\mathrm{C}_{6 \mathrm{~B}}\right)$ & 2843 & \\
\hline$v_{\mathrm{s}}\left(\mathrm{CH}_{2}\right) /\left(\mathrm{C}_{6 \mathrm{~B}}-\mathrm{H}_{6 \mathrm{~B}}, \mathrm{H}_{6 \mathrm{~B}}^{\prime}-\mathrm{C}_{6 \mathrm{~B}}\right)$ & 2795 & \\
\hline$v_{\text {as }}\left(\mathrm{CH}_{3}\right) /\left(\mathrm{C}_{10 \mathrm{~B}}-\mathrm{H}_{10 \mathrm{~B}}, \mathrm{H}^{\prime}{ }_{10 \mathrm{~B}}-\mathrm{C}_{10 \mathrm{~B}}\right)$ & 2784 & \\
\hline$v_{\text {as }}\left(\mathrm{CH}_{3}\right) /\left(\mathrm{C}_{10 \mathrm{~B}}-\mathrm{H}_{10 \mathrm{~B}}, \mathrm{H}^{\prime \prime}{ }_{10 \mathrm{~B}}-\mathrm{C}_{10 \mathrm{~B}}\right)$ & 2783 & \\
\hline$v_{\mathrm{s}}\left(\mathrm{CH}_{3}\right) /\left(\mathrm{C}_{10 \mathrm{~B}}-\mathrm{H}_{10 \mathrm{~B}}, \mathrm{H}^{\prime}{ }_{10 \mathrm{~B}}-\mathrm{C}_{10 \mathrm{~B}}, \mathrm{H}^{\prime \prime}{ }_{10 \mathrm{~B}}-\mathrm{C}_{10 \mathrm{~B}}\right)$ & 2731 & \\
\hline$\nu\left(\mathrm{CH}_{2}\right) /\left(\mathrm{C}_{8 \mathrm{~B}}-\mathrm{H}_{8 \mathrm{~B}}^{\prime}\right)$ & 2606 & 2618 \\
\hline$\nu(\mathrm{CO}) /\left(\mathrm{C}_{7 \mathrm{~B}}-\mathrm{O}_{1 \mathrm{~B}}\right)$ & 1707 & 1753 \\
\hline$\nu(\mathrm{CN})+\delta(\mathrm{CH})+\nu(\mathrm{C}=\mathrm{C}) /\left(\mathrm{C}_{1}-\mathrm{N}_{2}\right),\left(\mathrm{C}_{2}-\mathrm{H}_{2}\right),\left(\mathrm{C}_{2}-\mathrm{C}_{3}\right)$ & 1652 & \multirow{3}{*}{1645} \\
\hline$\nu(\mathrm{CN})+\nu(\mathrm{C}=\mathrm{C}) /\left(\mathrm{C}_{1}-\mathrm{N}_{1}\right),\left(\mathrm{C}_{2}-\mathrm{C}_{3}\right)$ & 1619 & \\
\hline$\delta_{\mathrm{sc}}\left(\mathrm{NH}_{2}\right) /\left(\mathrm{C}_{3 \mathrm{~B}}-\mathrm{H}_{3 \mathrm{~B}}, \mathrm{H}_{3 \mathrm{~B}}^{\prime}-\mathrm{C}_{3 \mathrm{~B}}\right)$ & 1606 & \\
\hline$v_{\mathrm{s}}(\mathrm{CN})+\nu(\mathrm{NC}) /\left(\mathrm{N}_{2}-\mathrm{C}_{1}, \mathrm{C}_{1}-\mathrm{N}_{1}\right),\left(\mathrm{N}_{2}-\mathrm{C}_{2}\right)$ & 1494 & 1561 \\
\hline$\delta_{\mathrm{sc}}\left(\mathrm{CH}_{3}\right)+\delta\left(\mathrm{CH}_{3}\right) /\left(\mathrm{C}_{10 \mathrm{~B}}-\mathrm{H}_{10 \mathrm{~B}}, \mathrm{C}_{10 \mathrm{~B}}-\mathrm{H}^{\prime \prime}{ }_{10 \mathrm{~B}}\right),\left(\mathrm{C}_{10 \mathrm{~B}}-\mathrm{H}^{\prime}{ }_{10 \mathrm{~B}}\right)$ & 1464 & \multirow{2}{*}{1528} \\
\hline$\delta_{\mathrm{sc}}\left(\mathrm{CH}_{2}\right) /\left(\mathrm{C}_{8 \mathrm{~B}}-\mathrm{H}_{8 \mathrm{~B}}, \mathrm{H}_{8 \mathrm{~B}}^{\prime}-\mathrm{C}_{8 \mathrm{~B}}\right)$ & 1462 & \\
\hline$\delta_{\mathrm{sc}}\left(\mathrm{CH}_{3}\right)+\delta\left(\mathrm{CH}_{3}\right) /\left(\mathrm{C}_{10 \mathrm{~B}}-\mathrm{H}^{\prime}{ }_{10 \mathrm{~B}}, \mathrm{C}_{10 \mathrm{~B}}-\mathrm{H}^{\prime \prime}{ }_{10 \mathrm{~B}}\right),\left(\mathrm{C}_{10 \mathrm{~B}}-\mathrm{H}_{10 \mathrm{~B}}\right)$ & 1451 & \multirow{2}{*}{1473} \\
\hline$\delta_{\mathrm{sc}}\left(\mathrm{CH}_{2}\right) /\left(\mathrm{C}_{6 \mathrm{~B}}-\mathrm{H}_{6 \mathrm{~B}}, \mathrm{H}_{6 \mathrm{~B}}^{\prime}-\mathrm{C}_{6 \mathrm{~B}}\right)$ & 1441 & \\
\hline$\delta_{\mathrm{sc}}\left(\mathrm{CH}_{2}\right)+\gamma_{\mathrm{w}}\left(\mathrm{CH}_{3}\right) /\left(\mathrm{C}_{9 \mathrm{~B}}-\mathrm{H}_{9 \mathrm{~B}}, \mathrm{H}^{\prime}{ }_{9 \mathrm{~B}}-\mathrm{C}_{9 \mathrm{~B}}\right),\left(\mathrm{C}_{10 \mathrm{~B}}-\mathrm{H}_{10 \mathrm{~B}}, \mathrm{C}_{10 \mathrm{~B}}-\mathrm{H}^{\prime}{ }_{10 \mathrm{~B}}\right)$ & 1415 & 1465 \\
\hline$\delta_{\mathrm{sc}}\left(\mathrm{CH}_{2}\right) /\left(\mathrm{C}_{5}-\mathrm{H}_{5}, \mathrm{H}^{\prime}{ }_{5}-\mathrm{C}_{5}\right)$ & 1381 & \multirow{2}{*}{1458} \\
\hline$\gamma_{\mathrm{w}}\left(\mathrm{CH}_{2}\right)+\delta_{\mathrm{sc}}\left(\mathrm{CH}_{2}\right) /\left(\mathrm{C}_{8 \mathrm{~B}}-\mathrm{H}_{8 \mathrm{~B}}, \mathrm{H}_{8 \mathrm{~B}}^{\prime}-\mathrm{C}_{8 \mathrm{~B}}\right),\left(\mathrm{C}_{4}-\mathrm{H}_{4}, \mathrm{H}_{4}^{\prime}-\mathrm{C}_{4}\right)$ & 1372 & \\
\hline$\gamma_{\mathrm{w}}\left(\mathrm{CH}_{2}\right)+\delta_{\mathrm{sc}}\left(\mathrm{CH}_{2}\right) /\left(\mathrm{C}_{6 \mathrm{~B}}-\mathrm{H}_{6 \mathrm{~B}}, \mathrm{H}_{6 \mathrm{~B}}^{\prime}-\mathrm{C}_{6 \mathrm{~B}}\right),\left(\mathrm{C}_{4}-\mathrm{H}_{4}, \mathrm{H}_{4}^{\prime}-\mathrm{C}_{4}\right)$ & 1352 & 1394 \\
\hline$v_{\mathrm{s}}(\mathrm{CN})+\gamma_{\mathrm{t}}\left(\mathrm{CH}_{2}\right) /\left(\mathrm{C}_{4}-\mathrm{N}_{2}, \mathrm{~N}_{1}-\mathrm{C}_{5}\right),\left(\mathrm{C}_{6 \mathrm{~B}}-\mathrm{H}_{6 \mathrm{~B}}, \mathrm{H}_{6 \mathrm{~B}}^{\prime}-\mathrm{C}_{6 \mathrm{~B}}\right),\left(\mathrm{C}_{5}-\mathrm{H}_{5}, \mathrm{H}^{\prime}{ }_{5}-\mathrm{C}_{5}\right)$ & 1319 & \multirow{2}{*}{1300} \\
\hline$\gamma_{\mathrm{w}}\left(\mathrm{CH}_{2}\right) /\left(\mathrm{C}_{9 \mathrm{~B}}-\mathrm{H}_{9 \mathrm{~B}}, \mathrm{H}^{\prime}{ }_{9 \mathrm{~B}}-\mathrm{C}_{9 \mathrm{~B}}\right)$ & 1309 & \\
\hline$\gamma_{\mathrm{t}}\left(\mathrm{NH}_{2}\right)+\gamma_{\mathrm{t}}\left(\mathrm{CH}_{2}\right) /\left(\mathrm{N}_{3 \mathrm{~B}}-\mathrm{H}_{3 \mathrm{~B}}, \mathrm{H}_{3 \mathrm{~B}}^{\prime}-\mathrm{N}_{3 \mathrm{~B}}\right),\left(\mathrm{C}_{6 \mathrm{~B}}-\mathrm{H}_{6 \mathrm{~B}}, \mathrm{H}_{6 \mathrm{~B}}^{\prime}-\mathrm{C}_{6 \mathrm{~B}}\right)$ & 1296 & \multirow{2}{*}{1242} \\
\hline$\delta(\mathrm{NCHN})+\delta_{\mathrm{r}}(\mathrm{CH}) /\left(\mathrm{C}_{1}-\mathrm{H}_{1}\right),\left(\mathrm{C}_{2}-\mathrm{H}_{2}, \mathrm{C}_{3}-\mathrm{H}_{3}\right)$ & 1282 & \\
\hline$\nu_{\mathrm{as}}(\mathrm{CO})+\gamma_{\mathrm{w}}\left(\mathrm{CH}_{2}\right) /\left(\mathrm{C}_{7 \mathrm{~B}}-\mathrm{O}_{2 \mathrm{~B}}, \mathrm{O}_{2 \mathrm{~B}}-\mathrm{C}_{9 \mathrm{~B}}\right),\left(\mathrm{C}_{5}-\mathrm{H}_{5}, \mathrm{H}^{\prime}{ }^{-} \mathrm{C}_{5}\right),\left(\mathrm{C}_{9 \mathrm{~B}}-\mathrm{H}_{9 \mathrm{~B}}, \mathrm{H}_{9 \mathrm{~B}}^{\prime}-\mathrm{C}_{9 \mathrm{~B}}\right)$ & 1248 & 1214 \\
\hline$\nu_{\mathrm{as}}(\mathrm{CO})+\gamma_{\mathrm{w}}\left(\mathrm{CH}_{3}\right) /\left(\mathrm{C}_{7 \mathrm{~B}}-\mathrm{O}_{2 \mathrm{~B}}, \mathrm{O}_{2 \mathrm{~B}}-\mathrm{C}_{9 \mathrm{~B}}\right),\left(\mathrm{C}_{10 \mathrm{~B}}-\mathrm{H}_{10 \mathrm{~B}}, \mathrm{C}_{10 \mathrm{~B}}-\mathrm{H}^{\prime \prime}{ }_{10 \mathrm{~B}}\right)$ & 1198 & 1183 \\
\hline$v_{\mathrm{as}}(\mathrm{CC})+v(\mathrm{CO})+v_{\mathrm{s}}(\mathrm{CN}) /\left(\mathrm{C}_{8 \mathrm{~B}}-\mathrm{C}_{6 \mathrm{~B}}, \mathrm{C}_{6 \mathrm{~B}}-\mathrm{C}_{4}\right),\left(\mathrm{C}_{3 \mathrm{~B}}-\mathrm{O}_{2 \mathrm{~B}}\right),\left(\mathrm{C}_{4}-\mathrm{N}_{2}, \mathrm{~N}_{1}-\mathrm{C}_{5}\right)$ & 1123 & 1118 \\
\hline$v_{\mathrm{s}}(\mathrm{CO})+\nu(\mathrm{CC})+\delta(\mathrm{NCHN}) /\left(\mathrm{C}_{7 \mathrm{~B}}-\mathrm{O}_{2 \mathrm{~B}}, \mathrm{O}_{2 \mathrm{~B}}-\mathrm{C}_{9 \mathrm{~B}}\right),\left(\mathrm{C}_{9 \mathrm{~B}}-\mathrm{C}_{10 \mathrm{~B}}\right),\left(\mathrm{C}_{7 \mathrm{~B}}-\mathrm{C}_{5}\right),\left(\mathrm{C}_{1}-\mathrm{H}_{1}\right)$ & 1069 & 1097 \\
\hline$\gamma_{\mathrm{w}}\left(\mathrm{NH}_{2}\right)+\delta_{\mathrm{r}}\left(\mathrm{CH}_{2}\right) /\left(\mathrm{N}_{3 \mathrm{~B}}-\mathrm{H}_{3 \mathrm{~B}}, \mathrm{H}^{\prime}{ }_{3 \mathrm{~B}}-\mathrm{N}_{3 \mathrm{~B}}\right),\left(\mathrm{C}_{8 \mathrm{~B}}-\mathrm{H}_{8 \mathrm{~B}}, \mathrm{H}_{8 \mathrm{~B}}^{\prime}-\mathrm{C}_{8 \mathrm{~B}}\right)$ & 1011 & 1039 \\
\hline$\gamma_{\mathrm{w}}\left(\mathrm{NH}_{2}\right)+\nu(\mathrm{CC}) /\left(\mathrm{N}_{3 \mathrm{~B}}-\mathrm{H}_{3 \mathrm{~B}}, \mathrm{H}_{3 \mathrm{~B}}^{\prime}-\mathrm{N}_{3 \mathrm{~B}}\right)+\left(\mathrm{C}_{6 \mathrm{~B}}-\mathrm{C}_{4}\right)$ & 869 & 931 \\
\hline$\nu(\mathrm{CC})+\gamma_{\mathrm{w}}\left(\mathrm{CH}_{3}\right)+\nu(\mathrm{CO}) /\left(\mathrm{C}_{5}-\mathrm{C}_{7 \mathrm{~B}}\right),\left(\mathrm{C}_{10 \mathrm{~B}}-\mathrm{H}_{10 \mathrm{~B}}, \mathrm{C}_{10 \mathrm{~B}}-\mathrm{H}^{\prime}{ }_{10 \mathrm{~B}}\right),\left(\mathrm{C}_{7 \mathrm{~B}}-\mathrm{O}_{2 \mathrm{~B}}\right)$ & 860 & 852 \\
\hline$\gamma_{\mathrm{w}}\left(\mathrm{NH}_{2}\right)+\nu(\mathrm{CC}) /\left(\mathrm{N}_{3 \mathrm{~B}}-\mathrm{H}_{3 \mathrm{~B}}, \mathrm{H}_{3 \mathrm{~B}}^{\prime}-\mathrm{N}_{3 \mathrm{~B}}\right),\left(\mathrm{C}_{4}-\mathrm{C}_{6 \mathrm{~B}}\right)$ & 824 & 787 \\
\hline$\gamma(\mathrm{NCHN})+\gamma_{\mathrm{w}}(\mathrm{CH}) /\left(\mathrm{C}_{1}-\mathrm{H}_{1}\right),\left(\mathrm{C}_{2}-\mathrm{H}_{2}, \mathrm{C}_{3}-\mathrm{H}_{3}\right)$ & 797 & 765 \\
\hline$\gamma_{\mathrm{w}}(\mathrm{CH})+\gamma_{\mathrm{t}}\left(\mathrm{NH}_{2}\right)+\gamma_{\mathrm{t}}(\mathrm{CN}) /\left(\mathrm{C}_{2}-\mathrm{H}_{2}, \mathrm{C}_{3}-\mathrm{H}_{3}\right),\left(\mathrm{N}_{3 \mathrm{~B}}-\mathrm{H}_{3 \mathrm{~B}}, \mathrm{H}_{3 \mathrm{~B}}^{\prime}-\mathrm{N}_{3 \mathrm{~B}}\right),\left(\mathrm{N}_{1}-\mathrm{C}_{5}\right)$ & 759 & 700 \\
\hline$\gamma_{\mathrm{t}}\left(\mathrm{NH}_{2}\right) \gamma_{\mathrm{t}}(\mathrm{CN})+\gamma(\mathrm{NCHN}) /\left(\mathrm{N}_{3 \mathrm{~B}}-\mathrm{H}_{3 \mathrm{~B}}, \mathrm{H}^{\prime}{ }_{3 \mathrm{~B}}-\mathrm{N}_{3 \mathrm{~B}}\right),\left(\mathrm{N}_{2}-\mathrm{C}_{4}\right),\left(\mathrm{C}_{1}-\mathrm{H}_{1}\right)$ & 722 & 652 \\
\hline$\gamma_{\mathrm{t}}\left(\mathrm{CH}_{2}\right)+\delta(\mathrm{CC}) /\left(\mathrm{C}_{8 \mathrm{~B}}-\mathrm{H}_{8 \mathrm{~B}}, \mathrm{H}_{8 \mathrm{~B}}^{\prime}-\mathrm{C}_{8 \mathrm{~B}}\right),\left(\mathrm{C}_{6 \mathrm{~B}}-\mathrm{H}_{6 \mathrm{~B}}, \mathrm{H}_{6 \mathrm{~B}}^{\prime}-\mathrm{C}_{6 \mathrm{~B}}\right),\left(\mathrm{C}_{5}-\mathrm{C}_{7 \mathrm{~B}}\right)$ & 665 & 636 \\
\hline$\gamma_{\mathrm{t}}\left(\mathrm{CH}_{2}\right)+\delta(\mathrm{CC}) /\left(\mathrm{C}_{6 \mathrm{~B}}-\mathrm{H}_{6 \mathrm{~B}}, \mathrm{H}_{6 \mathrm{~B}^{\prime}}^{\prime} \mathrm{C}_{6 \mathrm{~B}}\right)+\left(\mathrm{C}_{6 \mathrm{~B}}-\mathrm{C}_{4}\right)+\left(\mathrm{C}_{5}-\mathrm{C}_{7 \mathrm{~B}}\right)$ & 626 & \multirow{2}{*}{592} \\
\hline$\gamma_{\mathrm{t}}(\mathrm{C}=\mathrm{C}) /\left(\mathrm{N}_{2}-\mathrm{C}_{2}, \mathrm{C}_{3}-\mathrm{N}_{1}\right)$ & 603 & \\
\hline$\Gamma(\mathrm{NCHN}) /\left(\mathrm{C}_{1}-\mathrm{H}_{1}\right)$ & 534 & 534 \\
\hline
\end{tabular}

$\nu$, stretching; $\delta$, in-plane bending; $\gamma$, out-of-plane bending; s, symmetric; as, asymmetric; sc, scissoring; r, rocking; t, twisting; w, wagging.

The $R$-square test results exhibit $99.8 \%, 99.5 \%, 99.5 \%$, and 99.7\% agreement between the experimental and the theoretical IR spectra of $L_{\mathrm{A}}, L_{\mathrm{B}}, L_{\mathrm{C}}$, and $L_{\mathrm{D}}$, respectively.

The intermolecular interactions and the correlations of close frequency IR signals cause the $-\mathrm{OH},-\mathrm{CH},-\mathrm{CH}_{2},-\mathrm{CH}_{3}$, and $-\mathrm{NH}_{2}$ stretching vibrations to appear under broad peaks in the experimental spectra. These broad peaks are in very well-defined frequency region. The vibrations coming from the other functional groups of the imidazole rings and the aliphatic chains including the other vibrations of the hydrogenic groups in all modes appeared in $1750-450 \mathrm{~cm}^{-1}$ region.

The first vibration signals observed in the $1800-1700 \mathrm{~cm}^{-1}$ region of the experimental spectra of $L_{\mathrm{B}}, L_{\mathrm{C}}$, and $L_{\mathrm{D}}$ are distinct peaks arising from $v(\mathrm{C}=\mathrm{O})$ stretching as their values 
TABLE 5: The experimental and theoretical vibrational wave numbers for the infrared spectra of 1,3-bis(2-carboxyethyl)-4-methyl-1Himidazol-3-ium bromide $\left(L_{\mathrm{C}}\right)$ with its symbolled and numbered atoms in Figure 1(c).

\begin{tabular}{|c|c|c|}
\hline Vibrational assignments/vibrating atoms & Theory & Experiment \\
\hline$v(\mathrm{OH}) /\left(\mathrm{O}_{3 \mathrm{C}}-\mathrm{H}_{3 \mathrm{C}}\right)$ & 3685 & \multirow{7}{*}{3416} \\
\hline$v(\mathrm{OH}) /\left(\mathrm{O}_{4 \mathrm{C}}-\mathrm{H}_{4 \mathrm{C}}\right)$ & 3643 & \\
\hline$\nu\left(\mathrm{CH}_{2}\right) /\left(\mathrm{C}_{5}-\mathrm{H}_{5}\right)$ & 3328 & \\
\hline$v\left(\mathrm{CH}_{2}\right) /\left(\mathrm{C}_{4}-\mathrm{H}_{4}\right)$ & 3311 & \\
\hline$\nu(\mathrm{NCHN}) /\left(\mathrm{C}_{1}-\mathrm{H}_{1}\right)$ & 3292 & \\
\hline$v\left(\mathrm{CH}_{3}\right) /\left(\mathrm{C}_{10}-\mathrm{H}^{\prime \prime}{ }_{10 \mathrm{C}}\right)$ & 3046 & \\
\hline$v\left(\mathrm{CH}_{2}\right) /\left(\mathrm{C}_{5}-\mathrm{H}_{5}^{\prime}\right)$ & 2983 & \\
\hline$v\left(\mathrm{CH}_{2}\right) /\left(\mathrm{C}_{4}-\mathrm{H}_{4}^{\prime}\right)$ & 2949 & \multirow{6}{*}{$3268-2677$} \\
\hline$v_{\mathrm{as}}\left(\mathrm{CH}_{3}\right) /\left(\mathrm{C}_{10 \mathrm{C}}-\mathrm{H}_{10 \mathrm{C}}, \mathrm{H}^{\prime}{ }_{10 \mathrm{C}}-\mathrm{C}_{10 \mathrm{C}}\right)$ & 2904 & \\
\hline$v_{\mathrm{as}}\left(\mathrm{CH}_{2}\right) /\left(\mathrm{C}_{7 \mathrm{C}^{-}}-\mathrm{H}_{7 \mathrm{C}}, \mathrm{H}^{\prime}{ }_{7 \mathrm{C}^{-}}-\mathrm{C}_{7 \mathrm{C}}\right)$ & 2836 & \\
\hline$v_{\mathrm{as}}\left(\mathrm{CH}_{2}\right) /\left(\mathrm{C}_{6 \mathrm{C}}-\mathrm{H}_{6 \mathrm{C}}, \mathrm{H}^{\prime}{ }_{6 \mathrm{C}}-\mathrm{C}_{6 \mathrm{C}}\right)$ & 2828 & \\
\hline$v_{\mathrm{s}}\left(\mathrm{CH}_{2}\right) /\left(\mathrm{C}_{6 \mathrm{C}}-\mathrm{H}_{6 \mathrm{C}}, \mathrm{H}^{\prime}{ }_{6 \mathrm{C}}-\mathrm{C}_{6 \mathrm{C}}\right)$ & 2752 & \\
\hline$v_{\mathrm{s}}\left(\mathrm{CH}_{2}\right) /\left(\mathrm{C}_{7 \mathrm{C}}-\mathrm{H}_{7 \mathrm{C}}, \mathrm{H}^{\prime}{ }_{7 \mathrm{C}}-\mathrm{C}_{7 \mathrm{C}}\right)$ & 2739 & \\
\hline$\nu(\mathrm{CH}) /\left(\mathrm{C}_{2}-\mathrm{H}_{2}\right)$ & 2706 & \multirow[t]{2}{*}{2663} \\
\hline$v_{s}(\mathrm{COOH})+v_{s}(\mathrm{OH}) /\left(\mathrm{C}_{9 \mathrm{C}^{-}}-\mathrm{O}_{1 \mathrm{C}}, \mathrm{O}_{2 \mathrm{C}^{-}} \mathrm{C}_{8 \mathrm{C}}\right),\left(\mathrm{O}_{3 \mathrm{C}^{-}}-\mathrm{H}_{3 \mathrm{C}}, \mathrm{H}_{4 \mathrm{C}^{-}}-\mathrm{O}_{4 \mathrm{C}}\right)$ & 1785 & \\
\hline$v_{\mathrm{as}}(\mathrm{COOH})+v_{\mathrm{as}}(\mathrm{OH}) /\left(\mathrm{C}_{9 \mathrm{C}^{-}}-\mathrm{O}_{1 \mathrm{C}}, \mathrm{O}_{2 \mathrm{C}^{-}} \mathrm{C}_{8 \mathrm{C}}\right),\left(\mathrm{O}_{3 \mathrm{C}^{-}}-\mathrm{H}_{3 \mathrm{C}}, \mathrm{H}_{4 \mathrm{C}^{-}}-\mathrm{O}_{4 \mathrm{C}}\right)$ & 1783 & \multirow{2}{*}{1774} \\
\hline$v_{\mathrm{as}}(\mathrm{CN}) /\left(\mathrm{C}_{1}-\mathrm{N}_{1}, \mathrm{~N}_{2}-\mathrm{C}_{1}\right)$ & 1756 & \\
\hline$\nu_{\mathrm{as}}(\mathrm{CN})+\nu(\mathrm{CC})+\nu(\mathrm{CN}) /\left(\mathrm{C}_{1}-\mathrm{N}_{1}, \mathrm{~N}_{2}-\mathrm{C}_{5}\right),\left(\mathrm{C}_{6 \mathrm{C}^{-}}-\mathrm{C}_{4}\right),\left(\mathrm{N}_{2}-\mathrm{C}_{4}\right)$ & 1679 & \multirow{2}{*}{1662} \\
\hline$\nu_{\mathrm{s}}(\mathrm{CN})+\nu(\mathrm{C}=\mathrm{C})+\nu(\mathrm{CC}) /\left(\mathrm{C}_{1}-\mathrm{N}_{1}, \mathrm{~N}_{2}-\mathrm{C}_{1}\right),\left(\mathrm{C}_{2}-\mathrm{C}_{3}\right),\left(\mathrm{C}_{3}-\mathrm{C}_{10 \mathrm{C}}\right),\left(\mathrm{C}_{4}-\mathrm{N}_{2}\right)$ & 1642 & \\
\hline$\gamma_{\mathrm{t}}\left(\mathrm{CH}_{2}\right)+v(\mathrm{CN}) /\left(\mathrm{C}_{5}-\mathrm{H}_{5}, \mathrm{H}^{\prime}{ }_{5}-\mathrm{C}_{5}\right),\left(\mathrm{N}_{1}-\mathrm{C}_{3}\right)$ & 1510 & 1576 \\
\hline$\gamma_{\mathrm{t}}\left(\mathrm{CH}_{2}\right)+\nu(\mathrm{CN}) /\left(\mathrm{C}_{4}-\mathrm{H}_{4}, \mathrm{H}^{\prime}{ }_{4}-\mathrm{C}_{4}\right),\left(\mathrm{N}_{2}-\mathrm{C}_{2}\right)$ & 1476 & 1561 \\
\hline$\delta_{\mathrm{sc}}\left(\mathrm{CH}_{2}\right)+\delta_{\mathrm{sc}}\left(\mathrm{CH}_{3}\right) /\left(\mathrm{C}_{4}-\mathrm{H}_{4}, \mathrm{H}_{4}^{\prime}-\mathrm{C}_{4}\right),\left(\mathrm{C}_{6 \mathrm{C}}-\mathrm{H}_{6 \mathrm{C}}, \mathrm{H}^{\prime}{ }_{6 \mathrm{C}}-\mathrm{C}_{6 \mathrm{C}}\right),\left(\mathrm{C}_{10 \mathrm{C}}-\mathrm{H}_{10 \mathrm{C}}, \mathrm{C}_{10 \mathrm{C}}-\mathrm{H}^{\prime \prime}{ }_{10 \mathrm{C}}\right)$ & 1434 & 1468 \\
\hline$\gamma\left(\mathrm{CH}_{3}\right) /\left(\mathrm{C}_{10 \mathrm{C}}-\mathrm{H}_{10 \mathrm{C}}^{\prime}\right)$ & 1398 & 1393 \\
\hline$\delta(\mathrm{CH})+\gamma_{\mathrm{t}}\left(\mathrm{CH}_{2}\right)+\delta(\mathrm{NCHN}) /\left(\mathrm{C}_{2}-\mathrm{H}_{2}\right)+\left(\mathrm{C}_{4}-\mathrm{H}_{4}, \mathrm{H}^{\prime}{ }_{4}-\mathrm{C}_{4}\right)+\left(\mathrm{C}_{5}-\mathrm{H}_{5}, \mathrm{H}^{\prime}{ }_{5}-\mathrm{C}_{5}\right)+\left(\mathrm{C}_{1}-\mathrm{H}_{1}\right)$ & 1305 & 1317 \\
\hline$\delta(\mathrm{OH})+\nu(\mathrm{CO}) /\left(\mathrm{O}_{4 \mathrm{C}}-\mathrm{H}_{4 \mathrm{C}}\right),\left(\mathrm{C}_{8 \mathrm{C}}-\mathrm{O}_{4 \mathrm{C}}\right)$ & 1259 & 1282 \\
\hline$\delta(\mathrm{CH})+v(\mathrm{CC})+v(\mathrm{CN}) /\left(\mathrm{C}_{1}-\mathrm{H}_{1}\right),\left(\mathrm{C}_{2}-\mathrm{H}_{2}\right),\left(\mathrm{C}_{3}-\mathrm{C}_{10 \mathrm{C}}\right),\left(\mathrm{N}_{2}-\mathrm{C}_{4}\right)$ & 1239 & \multirow{2}{*}{1235} \\
\hline$\delta(\mathrm{CH})+\nu(\mathrm{CC})+v_{\mathrm{s}}(\mathrm{CN}) /\left(\mathrm{C}_{1}-\mathrm{H}_{1}\right),\left(\mathrm{C}_{2}-\mathrm{H}_{2}\right),\left(\mathrm{C}_{3}-\mathrm{C}_{10 \mathrm{C}}\right),\left(\mathrm{N}_{2}-\mathrm{C}_{4}, \mathrm{C}_{5}-\mathrm{N}_{1}\right)$ & 1221 & \\
\hline$\gamma_{\mathrm{t}}\left(\mathrm{CH}_{2}\right) /\left(\mathrm{C}_{4}-\mathrm{H}_{4}, \mathrm{H}_{4}^{\prime}-\mathrm{C}_{4}\right),\left(\mathrm{C}_{6 \mathrm{C}}-\mathrm{H}_{6 \mathrm{C}}, \mathrm{H}_{6 \mathrm{C}}^{\prime} \mathrm{C}_{6 \mathrm{C}}\right)$ & 1191 & \multirow[t]{2}{*}{1199} \\
\hline$\gamma_{\mathrm{t}}\left(\mathrm{CH}_{2}\right) /\left(\mathrm{C}_{5}-\mathrm{H}_{5}, \mathrm{H}^{\prime}{ }_{5}-\mathrm{C}_{5}\right),\left(\mathrm{C}_{7 \mathrm{C}^{-}}-\mathrm{H}_{7 \mathrm{C}}, \mathrm{H}^{\prime}{ }_{7 \mathrm{C}^{-}}-\mathrm{C}_{7 \mathrm{C}}\right)$ & 1181 & \\
\hline$\gamma_{\mathrm{w}}\left(\mathrm{CH}_{2}\right)+\delta(\mathrm{OH}) /\left(\mathrm{C}_{6 \mathrm{C}^{-}}-\mathrm{H}_{6 \mathrm{C}}, \mathrm{H}_{6 \mathrm{C}^{-}}^{\prime} \mathrm{C}_{6 \mathrm{C}}\right),\left(\mathrm{O}_{4 \mathrm{C}^{-}}-\mathrm{H}_{4 \mathrm{C}}\right)$ & 1149 & \multirow{2}{*}{1157} \\
\hline$\gamma_{\mathrm{w}}\left(\mathrm{CH}_{2}\right)+\delta(\mathrm{OH}) /\left(\mathrm{C}_{7 \mathrm{C}^{-}}-\mathrm{H}_{7 \mathrm{C}}, \mathrm{H}^{\prime} \mathrm{C}^{-} \mathrm{C}_{7 \mathrm{C}}\right),\left(\mathrm{O}_{3 \mathrm{C}^{-}}-\mathrm{H}_{3 \mathrm{C}}\right)$ & 1139 & \\
\hline$v(\mathrm{CC}) /\left(\mathrm{C}_{5}-\mathrm{C}_{7 \mathrm{C}}\right)$ & 1086 & \multirow{2}{*}{1099} \\
\hline$\nu(\mathrm{CC}) /\left(\mathrm{C}_{4}-\mathrm{C}_{6 \mathrm{C}}\right)$ & 1074 & \\
\hline$\delta\left(\mathrm{CH}_{3}\right) /\left(\mathrm{C}_{10}-\mathrm{H}_{10 \mathrm{C}}, \mathrm{C}_{10}-\mathrm{H}^{\prime}{ }_{10 \mathrm{C}}, \mathrm{C}_{10}-\mathrm{H}^{\prime \prime}{ }_{10 \mathrm{C}}\right)$ & 1046 & 1031 \\
\hline$\gamma\left(\mathrm{CH}_{3}\right)+\gamma(\mathrm{NCHN})+\gamma(\mathrm{CH}) /\left(\mathrm{C}_{10}-\mathrm{H}_{10 \mathrm{C}}, \mathrm{C}_{10}-\mathrm{H}_{10 \mathrm{C}}, \mathrm{C}_{10}-\mathrm{H}^{\prime \prime}{ }_{10 \mathrm{C}}\right),\left(\mathrm{C}_{1}-\mathrm{H}_{1}\right),\left(\mathrm{C}_{2}-\mathrm{H}_{2}\right)$ & 953 & 990 \\
\hline$\gamma_{\mathrm{w}}\left(\mathrm{CH}_{2}\right)+\delta_{\mathrm{r}}\left(\mathrm{CH}_{2}\right) /\left(\mathrm{C}_{6 \mathrm{C}}-\mathrm{H}_{6 \mathrm{C}}, \mathrm{H}_{6 \mathrm{C}}^{\prime}-\mathrm{C}_{6 \mathrm{C}}\right),\left(\mathrm{C}_{4}-\mathrm{H}_{4}, \mathrm{H}^{\prime}{ }_{4}-\mathrm{C}_{4}\right)$ & 940 & 931 \\
\hline$v(\mathrm{CC})+\delta_{\mathrm{r}}\left(\mathrm{CH}_{2}\right) /\left(\mathrm{C}_{3}-\mathrm{C}_{10}\right),\left(\mathrm{C}_{7 \mathrm{C}}-\mathrm{C}_{9 \mathrm{C}}\right),\left(\mathrm{C}_{4}-\mathrm{H}_{4}, \mathrm{H}^{\prime}{ }_{4}-\mathrm{C}_{4}\right),\left(\mathrm{C}_{6 \mathrm{C}}-\mathrm{H}_{6 \mathrm{C}}, \mathrm{H}^{\prime}{ }_{6 \mathrm{C}}-\mathrm{C}_{6 \mathrm{C}}\right)$ & 807 & \multirow{2}{*}{836} \\
\hline$\gamma(\mathrm{NCHN}) /\left(\mathrm{C}_{1}-\mathrm{H}_{1}\right)$ & 786 & \\
\hline$\gamma_{\mathrm{t}}(\mathrm{C}=\mathrm{C})+\delta(\mathrm{OH}) /\left(\mathrm{N}_{2}-\mathrm{C}_{2}, \mathrm{C}_{3}-\mathrm{N}_{1}\right)+\left(\mathrm{O}_{4 \mathrm{C}}-\mathrm{H}_{4 \mathrm{C}}\right)$ & 624 & 629 \\
\hline$\delta(\mathrm{OH}) /\left(\mathrm{O}_{4 \mathrm{C}}-\mathrm{H}_{4 \mathrm{C}}\right)$ & 470 & \multirow{2}{*}{462} \\
\hline$\delta(\mathrm{OH}) /\left(\mathrm{O}_{3 \mathrm{C}}-\mathrm{H}_{3 \mathrm{C}}\right)$ & 424 & \\
\hline
\end{tabular}

$\nu$, stretching; $\delta$, in-plane bending; $\gamma$, out-of-plane bending; s, symmetric; as, asymmetric; sc, scissoring; r, rocking; t, twisting; w, wagging.

in agreement with the previously observed $v(\mathrm{C}=\mathrm{O})$ stretching [25] and theoretically calculated values as reflected in Table 3. The imidazole $v(\mathrm{C}=\mathrm{N})$ stretching of $L_{\mathrm{A}}$ appears as individual signals while they are coupled under broad peaks with $L_{\mathrm{B}}, L_{\mathrm{C}}$, and $L_{\mathrm{D}}$ molecules as seen about $1650 \mathrm{~cm}^{-1}$ while the frequencies for $v(\mathrm{C}=\mathrm{N})$ stretching are in agreements with the corresponding data as given in [26]. The aliphatic $v(\mathrm{C}-\mathrm{N})$ stretching in $1069-1235 \mathrm{~cm}^{-1}$ interval and the aliphatic $v(\mathrm{C}$ C) stretching in $917-1099 \mathrm{~cm}^{-1}$ are consistent with the previous corresponding measurements [27].

Beyond the consistency of the common imidazole properties of the molecules, we also give unique infrared signals of molecules in Table 3. C-O stretching belong to the $\mathrm{H}_{2} \mathrm{C}-\mathrm{OH}$ group in $L_{\mathrm{A}}$, in-plane $\delta$ vibrations of $\mathrm{CH}_{3}$ at the end of the aliphatic chain of $L_{\mathrm{B}}$, and at the attachment of the imidazole ring of $L_{C}$ are such unique vibrations. The calculated and observed wave numbers of these vibrations are consistent with the concerning previous studies [28, 29].

The molecules in consideration analyzed by infrared spectrum because of the lack of exchangeable protons of $-\mathrm{OH}$ and $-\mathrm{NH}_{2}$ in the NMR spectra of the chemicals and the existence of these groups is proved in the molecules. Also, the IR spectra of the molecules reverifies the theoretically obtained configurations of them as they were first verified by the comparison the theoretical NMR spectra with that of the experimental NMR spectra.

3.4. Antibacterial and Cytotoxic Activities. The antibacterial tests of the synthesized four molecules were run on the six 
TABLE 6: The experimental and theoretical vibrational wave numbers for the infrared spectra of 3-(2-carboxyethyl)-1-(3-aminopropyl)-1Himidazol-3-ium bromide $\left(L_{\mathrm{D}}\right)$ with its symbolled and numbered atoms in Figure 1(d).

\begin{tabular}{|c|c|c|}
\hline Vibrational assignments/vibrating atoms & Theory & Experiment \\
\hline$v(\mathrm{OH}) /\left(\mathrm{O}_{2 \mathrm{D}}-\mathrm{H}_{2 \mathrm{D}}\right)$ & 3590 & \multirow{3}{*}{3423} \\
\hline$\nu_{\mathrm{as}}\left(\mathrm{NH}_{2}\right) /\left(\mathrm{N}_{3 \mathrm{D}}-\mathrm{H}_{3 \mathrm{D}}, \mathrm{H}_{3 \mathrm{D}}^{\prime}-\mathrm{N}_{3 \mathrm{D}}\right)$ & 3446 & \\
\hline$v\left(\mathrm{CH}_{2}\right) /\left(\mathrm{C}_{4}-\mathrm{H}_{4}\right)$ & 3381 & \\
\hline$v_{\mathrm{s}}\left(\mathrm{NH}_{2}\right) /\left(\mathrm{N}_{3 \mathrm{D}}-\mathrm{H}_{3 \mathrm{D}}, \mathrm{H}_{3 \mathrm{D}}^{\prime}-\mathrm{N}_{3 \mathrm{D}}\right)$ & 3370 & \multirow[t]{6}{*}{$3222-2666$} \\
\hline$v\left(\mathrm{CH}_{2}\right) /\left(\mathrm{C}_{5}-\mathrm{H}_{5}\right)$ & 3154 & \\
\hline$v\left(\mathrm{CH}_{2}\right) /\left(\mathrm{C}_{8 \mathrm{D}}-\mathrm{H}_{8 \mathrm{D}}\right)$ & 3152 & \\
\hline$\nu(\mathrm{NCHN}) /\left(\mathrm{C}_{1}-\mathrm{H}_{1}\right)$ & 2995 & \\
\hline$v\left(\mathrm{CH}_{2}\right) /\left(\mathrm{C}_{6 \mathrm{D}}-\mathrm{H}_{6 \mathrm{D}}\right)$ & 2890 & \\
\hline$v_{\mathrm{s}}(\mathrm{CH}) /\left(\mathrm{C}_{2}-\mathrm{H}_{2}, \mathrm{H}_{3}-\mathrm{C}_{3}\right)$ & 2857 & \\
\hline$v_{\mathrm{as}}\left(\mathrm{CH}_{2}\right) /\left(\mathrm{C}_{7 \mathrm{D}}-\mathrm{H}_{7 \mathrm{D}}, \mathrm{H}^{\prime}{ }_{7 \mathrm{D}}-\mathrm{C}_{7 \mathrm{D}}\right)$ & 2850 & \multirow[t]{5}{*}{-} \\
\hline$v_{\mathrm{as}}(\mathrm{CH})+v_{\mathrm{s}}\left(\mathrm{CH}_{2}\right) /\left(\mathrm{C}_{2}-\mathrm{H}_{2}, \mathrm{H}_{3}-\mathrm{C}_{3}\right),\left(\mathrm{C}_{5}-\mathrm{H}_{5}, \mathrm{H}^{\prime}{ }_{5}-\mathrm{C}_{5}\right)$ & 2828 & \\
\hline$v_{\mathrm{s}}\left(\mathrm{CH}_{2}\right) /\left(\mathrm{C}_{7 \mathrm{D}}-\mathrm{H}_{7 \mathrm{D}}, \mathrm{H}_{7 \mathrm{D}}^{\prime}-\mathrm{C}_{7 \mathrm{D}}\right)$ & 2789 & \\
\hline$v\left(\mathrm{CH}_{2}\right) /\left(\mathrm{C}_{4}-\mathrm{H}_{4}^{\prime}\right)$ & 2752 & \\
\hline$\nu\left(\mathrm{CH}_{2}\right) /\left(\mathrm{C}_{8 \mathrm{D}}-\mathrm{H}_{8 \mathrm{D}}^{\prime}\right)$ & 2709 & \\
\hline$\nu(\mathrm{COOH}) /\left(\mathrm{C}_{9 \mathrm{D}}-\mathrm{O}_{1 \mathrm{D}}\right)$ & 1728 & 1745 \\
\hline$\nu_{\mathrm{s}}(\mathrm{CN})+\nu(\mathrm{C}=\mathrm{C}) /\left(\mathrm{C}_{1}-\mathrm{N}_{1}, \mathrm{~N}_{2}-\mathrm{C}_{1}\right),\left(\mathrm{C}_{2}-\mathrm{C}_{3}\right)$ & 1668 & 1642 \\
\hline$\nu_{\mathrm{as}}(\mathrm{CN})+\delta_{\mathrm{r}}(\mathrm{CH}) /\left(\mathrm{C}_{1}-\mathrm{N}_{1}, \mathrm{~N}_{2}-\mathrm{C}_{1}\right),\left(\mathrm{C}_{2}-\mathrm{H}_{2}, \mathrm{H}_{3}-\mathrm{C}_{3}\right)$ & 1601 & \multirow{2}{*}{1585} \\
\hline$\delta_{\mathrm{sc}}\left(\mathrm{NH}_{2}\right) /\left(\mathrm{N}_{3 \mathrm{D}}-\mathrm{H}_{3 \mathrm{D}}, \mathrm{H}_{3 \mathrm{D}}^{\prime}-\mathrm{N}_{3 \mathrm{D}}\right)$ & 1582 & \\
\hline$v_{\mathrm{s}}(\mathrm{CN}) /\left(\mathrm{C}_{1}-\mathrm{N}_{1}, \mathrm{~N}_{2}-\mathrm{C}_{1}\right)$ & 1468 & \multirow{3}{*}{1470} \\
\hline$\delta_{\mathrm{sc}}\left(\mathrm{CH}_{2}\right) /\left(\mathrm{C}_{6 \mathrm{D}}-\mathrm{H}_{6 \mathrm{D}}, \mathrm{H}_{6 \mathrm{D}}^{\prime}-\mathrm{C}_{6 \mathrm{D}}\right)$ & 1454 & \\
\hline$\delta_{\mathrm{sc}}\left(\mathrm{CH}_{2}\right) /\left(\mathrm{C}_{8 \mathrm{D}}-\mathrm{H}_{8 \mathrm{D}}, \mathrm{H}_{8 \mathrm{D}}^{\prime}-\mathrm{C}_{8 \mathrm{D}}\right)$ & 1443 & \\
\hline$\delta_{\mathrm{sc}}\left(\mathrm{CH}_{2}\right)+\gamma_{\mathrm{w}}\left(\mathrm{CH}_{2}\right) /\left(\mathrm{C}_{5}-\mathrm{H}_{5}, \mathrm{H}^{\prime}{ }_{5}-\mathrm{C}_{5}\right),\left(\mathrm{C}_{7 \mathrm{D}}-\mathrm{H}_{7 \mathrm{D}}, \mathrm{H}^{\prime}{ }_{7 \mathrm{D}}-\mathrm{C}_{7 \mathrm{D}}\right)$ & 1430 & \multirow[t]{3}{*}{1419} \\
\hline$\delta_{\mathrm{sc}}\left(\mathrm{CH}_{2}\right) /\left(\mathrm{C}_{4}-\mathrm{H}_{4}, \mathrm{H}_{4}^{\prime}-\mathrm{C}_{4}\right)$ & 1423 & \\
\hline$\gamma_{\mathrm{w}}\left(\mathrm{CH}_{2}\right)+\nu(\mathrm{CC})+\nu(\mathrm{CO}) /\left(\mathrm{C}_{7 \mathrm{D}}-\mathrm{H}_{7 \mathrm{D}}, \mathrm{H}_{7 \mathrm{D}}^{\prime} \mathrm{C}_{7 \mathrm{D}}\right),\left(\mathrm{C}_{7 \mathrm{D}}-\mathrm{C}_{9 \mathrm{D}}\right)+\left(\mathrm{C}_{9 \mathrm{D}}-\mathrm{O}_{2 \mathrm{D}}\right)$ & 1417 & \\
\hline$\delta_{\mathrm{sc}}\left(\mathrm{CH}_{2}\right) /\left(\mathrm{C}_{7 \mathrm{D}}-\mathrm{H}_{7 \mathrm{D}}, \mathrm{H}^{\prime}{ }_{7 \mathrm{D}}-\mathrm{C}_{7 \mathrm{D}}\right)$ & 1404 & \multirow{3}{*}{1354} \\
\hline$\delta(\mathrm{NCHN})+\delta_{\mathrm{r}}(\mathrm{CH}) /\left(\mathrm{C}_{1}-\mathrm{H}_{1}\right),\left(\mathrm{C}_{2}-\mathrm{H}_{2}, \mathrm{H}_{3}-\mathrm{C}_{3}\right)$ & 1372 & \\
\hline$\gamma_{\mathrm{w}}\left(\mathrm{CH}_{2}\right)+\nu(\mathrm{CC}) /\left(\mathrm{C}_{4}-\mathrm{H}_{4}, \mathrm{H}^{\prime}{ }_{4}-\mathrm{C}_{4}\right),\left(\mathrm{C}_{6 \mathrm{D}}-\mathrm{H}_{6 \mathrm{D}}, \mathrm{H}_{6 \mathrm{D}}^{\prime}-\mathrm{C}_{6 \mathrm{D}}\right),\left(\mathrm{C}_{6 \mathrm{D}}-\mathrm{C}_{8 \mathrm{D}}\right)$ & 1369 & \\
\hline$\gamma_{\mathrm{w}}\left(\mathrm{CH}_{2}\right)+\gamma_{\mathrm{t}}\left(\mathrm{NH}_{2}\right) /\left(\mathrm{C}_{4}-\mathrm{H}_{4}, \mathrm{H}^{\prime}{ }_{4}-\mathrm{C}_{4}\right),\left(\mathrm{C}_{6 \mathrm{D}}-\mathrm{H}_{6 \mathrm{D}}, \mathrm{H}^{\prime}{ }_{6 \mathrm{D}}-\mathrm{C}_{6 \mathrm{D}}\right),\left(\mathrm{N}_{3 \mathrm{D}}-\mathrm{H}_{3 \mathrm{D}}, \mathrm{H}^{\prime}{ }_{3 \mathrm{D}}-\mathrm{N}_{3 \mathrm{D}}\right)$ & 1348 & \multirow{3}{*}{1318} \\
\hline$\gamma_{\mathrm{w}}\left(\mathrm{CH}_{2}\right) /\left(\mathrm{C}_{5}-\mathrm{H}_{5}, \mathrm{H}^{\prime}{ }_{5}-\mathrm{C}_{5}\right),\left(\mathrm{C}_{7 \mathrm{D}}-\mathrm{H}_{7 \mathrm{D}}, \mathrm{H}^{\prime}{ }_{7 \mathrm{D}}-\mathrm{C}_{7 \mathrm{D}}\right)$ & 1344 & \\
\hline$\delta_{\mathrm{r}}(\mathrm{CH})+\gamma_{\mathrm{t}}\left(\mathrm{CH}_{2}\right)+\gamma_{\mathrm{w}}\left(\mathrm{CH}_{2}\right) /\left(\mathrm{C}_{2}-\mathrm{H}_{2}, \mathrm{H}_{3}-\mathrm{C}_{3}\right),\left(\mathrm{C}_{5}-\mathrm{H}_{5}, \mathrm{H}^{\prime}{ }_{5}-\mathrm{C}_{5}\right),\left(\mathrm{C}_{8 \mathrm{D}}-\mathrm{H}_{8 \mathrm{D}}, \mathrm{H}_{8 \mathrm{D}}^{\prime}-\mathrm{C}_{8 \mathrm{D}}\right)$ & 1314 & \\
\hline$\delta(\mathrm{NCHN})+\delta_{\mathrm{r}}(\mathrm{CH})+\delta(\mathrm{OH}) /\left(\mathrm{C}_{1}-\mathrm{H}_{1}\right),\left(\mathrm{C}_{2}-\mathrm{H}_{2}, \mathrm{H}_{3}-\mathrm{C}_{3}\right),\left(\mathrm{O}_{2 \mathrm{D}}-\mathrm{H}_{2 \mathrm{D}}\right)$ & 1298 & \multirow[t]{2}{*}{1297} \\
\hline$\gamma_{\mathrm{w}}\left(\mathrm{CH}_{2}\right)+\delta(\mathrm{OH}) /\left(\mathrm{C}_{7 \mathrm{D}}-\mathrm{H}_{7 \mathrm{D}}, \mathrm{H}^{\prime}{ }_{7 \mathrm{D}}-\mathrm{C}_{7 \mathrm{D}}\right),\left(\mathrm{O}_{2 \mathrm{D}}-\mathrm{H}_{2 \mathrm{D}}\right)$ & 1283 & \\
\hline$\gamma_{\mathrm{t}}\left(\mathrm{NH}_{2}\right)+\gamma_{\mathrm{t}}\left(\mathrm{CH}_{2}\right) /\left(\mathrm{N}_{3 \mathrm{D}}-\mathrm{H}_{3 \mathrm{D}}, \mathrm{H}^{\prime}{ }_{3 \mathrm{D}}-\mathrm{N}_{3 \mathrm{D}}\right),\left(\mathrm{C}_{6 \mathrm{D}}-\mathrm{H}_{6 \mathrm{D}}, \mathrm{H}^{\prime}{ }_{6 \mathrm{D}}-\mathrm{C}_{6 \mathrm{D}}\right)$ & 1266 & \multirow{2}{*}{1225} \\
\hline$\gamma_{\mathrm{t}}\left(\mathrm{NH}_{2}\right) /\left(\mathrm{N}_{3 \mathrm{D}}-\mathrm{H}_{3 \mathrm{D}}, \mathrm{H}_{3 \mathrm{D}}^{\prime}-\mathrm{N}_{3 \mathrm{D}}\right)$ & 1209 & \\
\hline$\delta_{\mathrm{sc}}(\mathrm{CH})+\delta(\mathrm{CH})+\gamma_{\mathrm{t}}\left(\mathrm{CH}_{2}\right) /\left(\mathrm{C}_{2}-\mathrm{H}_{2}, \mathrm{H}_{3}-\mathrm{C}_{3}\right),\left(\mathrm{C}_{1}-\mathrm{H}_{1}\right),\left(\mathrm{C}_{4}-\mathrm{H}_{4}, \mathrm{H}_{4}^{\prime}-\mathrm{C}_{4}\right)$ & 1178 & 1174 \\
\hline$\delta_{\mathrm{sc}}(\mathrm{CH}) /\left(\mathrm{C}_{2}-\mathrm{H}_{2}, \mathrm{H}_{3}-\mathrm{C}_{3}\right)$ & 1148 & \multirow{2}{*}{1119} \\
\hline$\delta(\mathrm{NCHN})+\gamma_{\mathrm{w}}\left(\mathrm{CH}_{2}\right)+\delta(\mathrm{OH}) /\left(\mathrm{C}_{1}-\mathrm{H}_{1}\right),\left(\mathrm{C}_{7 \mathrm{D}}-\mathrm{H}_{7 \mathrm{D}}, \mathrm{H}^{\prime}{ }_{7 \mathrm{D}}-\mathrm{C}_{7 \mathrm{D}}\right),\left(\mathrm{O}_{2 \mathrm{D}}-\mathrm{H}_{2 \mathrm{D}}\right)$ & 1139 & \\
\hline$\delta(\mathrm{NCHN})+\gamma_{\mathrm{t}}\left(\mathrm{CH}_{2}\right)+\gamma_{\mathrm{t}}\left(\mathrm{NH}_{2}\right) /\left(\mathrm{C}_{1}-\mathrm{H}_{1}\right),\left(\mathrm{C}_{5}-\mathrm{H}_{5}, \mathrm{H}^{\prime}{ }_{5}-\mathrm{C}_{5}\right),\left(\mathrm{N}_{3 \mathrm{D}}-\mathrm{H}_{3 \mathrm{D}}, \mathrm{H}^{\prime}{ }_{3 \mathrm{D}}-\mathrm{N}_{3 \mathrm{D}}\right)$ & 1111 & 1098 \\
\hline$\gamma_{\mathrm{t}}\left(\mathrm{NH}_{2}\right)+\delta_{\mathrm{sc}}(\mathrm{CH})+v_{\mathrm{as}}(\mathrm{CN}) /\left(\mathrm{N}_{3 \mathrm{D}}-\mathrm{H}_{3 \mathrm{D}}, \mathrm{H}_{3 \mathrm{D}}^{\prime}-\mathrm{N}_{3 \mathrm{D}}\right),\left(\mathrm{C}_{2}-\mathrm{H}_{2}, \mathrm{H}_{3}-\mathrm{C}_{3}\right),\left(\mathrm{C}_{4}-\mathrm{N}_{2}, \mathrm{~N}_{1}-\mathrm{C}_{5}\right)$ & 1070 & 1069 \\
\hline$\nu(\mathrm{CC}) /\left(\mathrm{C}_{5}-\mathrm{C}_{7 \mathrm{D}}\right)$ & 1037 & \multirow{3}{*}{1033} \\
\hline$\gamma_{\mathrm{w}}\left(\mathrm{NH}_{2}\right)+\nu(\mathrm{CC})+\nu(\mathrm{CN}) /\left(\mathrm{N}_{3 \mathrm{D}}-\mathrm{H}_{3 \mathrm{D}}, \mathrm{H}_{3 \mathrm{D}}^{\prime}-\mathrm{N}_{3 \mathrm{D}}\right),\left(\mathrm{C}_{6 \mathrm{D}}-\mathrm{C}_{4}\right),\left(\mathrm{C}_{4}-\mathrm{N}_{2}\right)$ & 1034 & \\
\hline$\gamma_{\mathrm{t}}(\mathrm{CH}) /\left(\mathrm{C}_{2}-\mathrm{H}_{2}, \mathrm{H}_{3}-\mathrm{C}_{3}\right)$ & 973 & \\
\hline$\gamma_{\mathrm{w}}\left(\mathrm{CH}_{2}\right)+\delta_{\mathrm{r}}\left(\mathrm{CH}_{2}\right)+\delta(\mathrm{OH}) /\left(\mathrm{C}_{7 \mathrm{D}}-\mathrm{H}_{7 \mathrm{D}}, \mathrm{H}^{\prime}{ }_{7 \mathrm{D}}-\mathrm{C}_{7 \mathrm{D}}\right),\left(\mathrm{C}_{5}-\mathrm{H}_{5}, \mathrm{H}^{\prime}{ }^{-} \mathrm{C}_{5}\right),\left(\mathrm{O}_{2 \mathrm{D}}-\mathrm{H}_{2 \mathrm{D}}\right)$ & 960 & \multirow[t]{2}{*}{976} \\
\hline$\gamma_{\mathrm{t}}\left(\mathrm{NH}_{2}\right)+\nu(\mathrm{CC}) /\left(\mathrm{N}_{3 \mathrm{D}}-\mathrm{H}_{3 \mathrm{D}}, \mathrm{H}_{3 \mathrm{D}}^{\prime}-\mathrm{N}_{3 \mathrm{D}}\right),\left(\mathrm{C}_{6 \mathrm{D}}-\mathrm{C}_{8 \mathrm{D}}\right)$ & 948 & \\
\hline$\gamma(\mathrm{NCHN})+\gamma_{\mathrm{w}}(\mathrm{CH}) /\left(\mathrm{C}_{1}-\mathrm{H}_{1}\right),\left(\mathrm{C}_{2}-\mathrm{H}_{2}, \mathrm{H}_{3}-\mathrm{C}_{3}\right)$ & 918 & 954 \\
\hline$\gamma_{\mathrm{t}}\left(\mathrm{NH}_{2}\right)+v(\mathrm{CN})+\delta_{\mathrm{r}}\left(\mathrm{CH}_{2}\right) /\left(\mathrm{N}_{3 \mathrm{D}}-\mathrm{H}_{3 \mathrm{D}}, \mathrm{H}_{3 \mathrm{D}}^{\prime}-\mathrm{N}_{3 \mathrm{D}}\right),\left(\mathrm{N}_{3 \mathrm{D}}-\mathrm{C}_{8 \mathrm{D}}\right),\left(\mathrm{C}_{6 \mathrm{D}}-\mathrm{H}_{6 \mathrm{D}}, \mathrm{H}_{6 \mathrm{D}}^{\prime}-\mathrm{C}_{6 \mathrm{D}}\right)$ & 818 & 846 \\
\hline$v_{\mathrm{s}}(\mathrm{CC})+\nu(\mathrm{CO})+\delta(\mathrm{OH}) /\left(\mathrm{C}_{5}-\mathrm{C}_{7 \mathrm{D}}, \mathrm{C}_{7 \mathrm{D}}-\mathrm{C}_{9 \mathrm{D}}\right),\left(\mathrm{C}_{9 \mathrm{D}}-\mathrm{O}_{2 \mathrm{D}}\right),\left(\mathrm{O}_{2 \mathrm{D}}-\mathrm{H}_{2 \mathrm{D}}\right)$ & 801 & 767 \\
\hline$\gamma_{\mathrm{t}}(\mathrm{C}=\mathrm{C})+\delta(\mathrm{OH}) /\left(\mathrm{C}_{2}-\mathrm{C}_{3}\right),\left(\mathrm{O}_{2 \mathrm{D}}-\mathrm{H}_{2 \mathrm{D}}\right)$ & 663 & 637 \\
\hline$\delta(\mathrm{OH})+\delta_{\mathrm{r}}\left(\mathrm{CH}_{2}\right) /\left(\mathrm{O}_{2 \mathrm{D}}-\mathrm{H}_{2 \mathrm{D}}\right),\left(\mathrm{C}_{7 \mathrm{D}}-\mathrm{H}_{7 \mathrm{D}}, \mathrm{H}^{\prime}{ }_{7 \mathrm{D}}-\mathrm{C}_{7 \mathrm{D}}\right)$ & 530 & - \\
\hline
\end{tabular}

$\nu$, stretching; $\delta$, in-plane bending; $\gamma$, out-of-plane bending; s, symmetric; as, asymmetric; sc, scissoring; r, rocking; t, twisting; w, wagging.

different bacteria and yeast, as mentioned in Section 2.3.1. Figures $2(a)$ and $3(b)$ show the inhibitory effects of the various concentrations of the $L_{\mathrm{A}}$ and $L_{\mathrm{B}}$ on Candida albicans ATCC 10231 and Bacillus cereus ATCC 11778 (Gram positive) together with that of the antibiotic controls. Their effects on Escherichia coli O157:H7 (Gram negative), Escherichia coli ATCC 25922, Salmonella typhimurium
ATCC 14028, Staphylococcus aureus ATCC 25923, and Listeria monocytogenes ATCC 19115 are excluded because of their very weak efficacy in comparison with that of the antibiotic control. Although the absorbance measurements involve some statistical errors, $L_{\mathrm{A}}$ showed better inhibition than the antibiotic on Bacillus cereus ATCC 11778, while both chemicals are effective on the selected bacteria and 


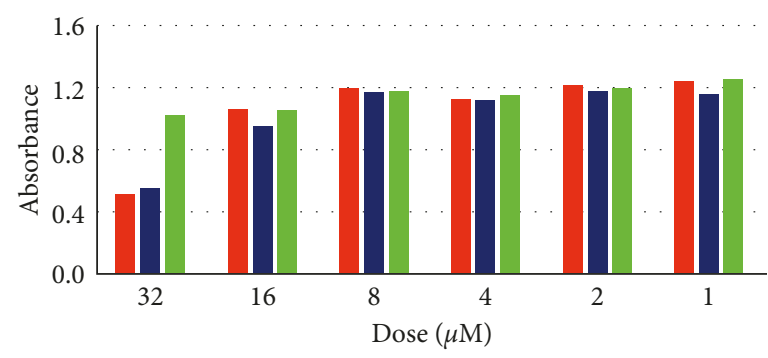

(a)

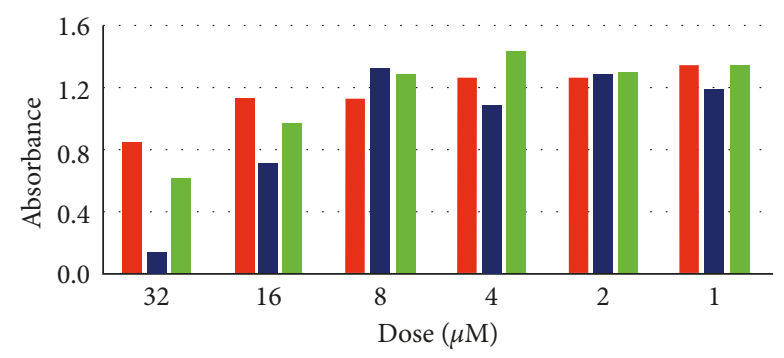

(b)

Figure 2: (a) The antibacterial activity on Candida albicans. The first bars on the left are for the commercial antibiotic inhibition for each dose. The second bars are for 1,3-bis(2-hydroxyethyl) imidazolidinium bromide $\left(L_{\mathrm{A}}\right)$, and the third bars are for 3-(2-ethoxy-2-oxoethly)-1(3-aminopropyl)-1H-imidazol-3-ium bromide $\left(L_{\mathrm{B}}\right)$, (b) same as in Figure 2(a), but for the antibacterial activity on Bacillus cereus.

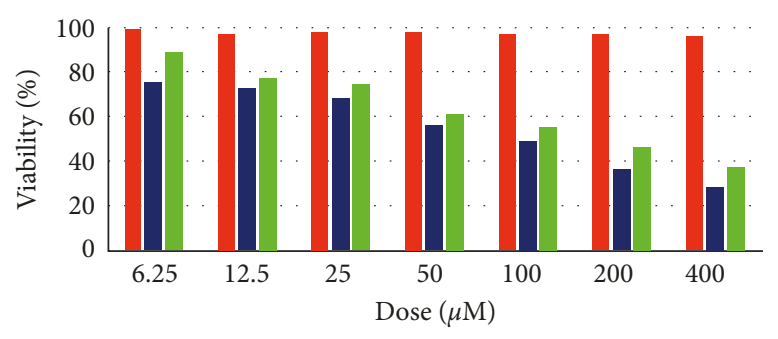

(a)

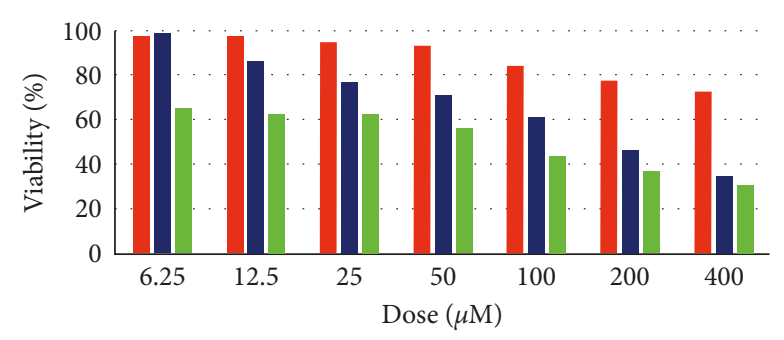

(b)

Figure 3: (a) The cytotoxicity of 1,3-bis(2-carboxyethyl)-4-methyl-1H-imidazol-3-ium bromide. The first bars represent the effect on healthy mouse embryonic fibroblast cell line for each dose, as do the second bars on human cervical cancer cell line, and the third bars on human liver cancer cell line, (b) same as in Figure 3(a), but for the cytotoxicity of 3-(2-carboxyethyl)-1-(3-aminopropyl)-1H-imidazol-3-ium bromide.

TABLE 7: Half inhibition concentrations of the molecules on the selected bacteria and cancer cell lines.

\begin{tabular}{|c|c|c|c|c|c|c|}
\hline & \multicolumn{3}{|c|}{ Antibacterial activity $\mathrm{IC}_{50}(\mu \mathrm{M})$} & \multicolumn{3}{|c|}{ Cytotoxic activity $\mathrm{IC}_{50}(\mu \mathrm{M})$} \\
\hline & Escherichia coli $\mathrm{O} 157: \mathrm{H7}$ & Candida albicans & Bacillus cereus & $\mathrm{HeLa}$ & Hep G2 & MEF \\
\hline$\overline{L_{\mathrm{A}}}$ & 32 & 30 & 17 & 316 & 100 & - \\
\hline$L_{\mathrm{B}}$ & 39 & 156 & 29 & 141 & 182 & - \\
\hline$L_{\mathrm{C}}$ & - & - & - & 81 & 150 & - \\
\hline$L_{\mathrm{D}}$ & - & - & - & 167 & 57 & - \\
\hline Antibiotic & 10 & 30 & 56 & - & - & - \\
\hline
\end{tabular}

$L_{\mathrm{A}}$, 1,3-bis(2-hydroxyethyl) imidazolidinium bromide; $L_{\mathrm{B}}$, 3-(2-ethoxy-2-oxoethly)-1-(3-aminopropyl)-1H-imidazol-3-ium bromide; $L_{\mathrm{C}}, 1,3$-bis(2-carboxyethyl)-4-methyl-1H-imidazol-3-ium bromide; $L_{\mathrm{D}}$ 3-(2-carboxyethyl)-1-(3-aminopropyl)-1H-imidazol-3-ium bromide; $\mathrm{IC}_{50}$, half inhibitory concentrations; HeLa, human cervical cancer cell line; Hep G2, human liver cancer cell line; MEF, healthy mouse embryonic fibroblast cell line.

yeast as much as the antibiotics. $L_{\mathrm{C}}$ and $L_{\mathrm{D}}$ show no noticeable inhibitory effects on the target bacteria, and thus, their absorbance values as function of their concentration were not given for the sake of brevity.

Figure 3(a) shows the cytotoxic activity of $L_{\mathrm{C}}$ on HeLa and Hep G2 cell lines against healthy MEF cell lines, as does Figure 3(b) for the cytotoxic activity of $L_{\mathrm{D}}$. The cytotoxic activities of $L_{\mathrm{A}}$ and $L_{\mathrm{B}}$ are not exhibited as they showed lesser cytotoxic activities in comparison with $L_{C}$ and $L_{D}$. The percentage cell viability of HeLa and Hep G2 cell lines was significantly reduced by $L_{\mathrm{C}}$ and $L_{\mathrm{D}}$ at the end of $24 \mathrm{hr}$ application of the doses. In addition, $L_{\mathrm{C}}$ did not harm the healthy MEF cell lines for any dose so that its half inhibitory concentrations $\left(\mathrm{IC}_{50}\right)$ cannot be calculated. Meantime, $L_{\mathrm{D}}$ showed some activity on the MEF cells with the high doses together with the fact that the activity was not as strong as it did on the cancer cell lines.

The antibacterial and cytotoxic effectiveness of the synthesized molecules are summarized in Table 7 by presenting their $\mathrm{IC}_{50}$ concentrations in the units of $\mu \mathrm{M}$ on the bacteria together with the $\mathrm{IC}_{50}$ values of the antibiotics and on the cancer cell lines. The lack of the $\mathrm{IC}_{50}$ values of $L_{\mathrm{C}}$ and $L_{\mathrm{D}}$ for antibacterial activity in Table 7 indicates that the $\mathrm{IC}_{50}$ values of them cannot be calculated due to their very weak effect on the bacteria sample within the dose range considered. $L_{\mathrm{A}}$ and $L_{\mathrm{B}}$ were, respectively, thrice and twice more effective on Bacillus cereus than the antibiotic (gentamicin) as the $L_{\mathrm{A}}$ equals the antibiotic (amphotericin-b) effect on Candida albicans. 
The cell viability assay of the chemicals exhibits no harmful effect on the healthy MEF cell lines as their IC $_{50}$ values cannot be calculated within the dose range considered. The $L_{\mathrm{C}}$ inhibition on HeLa and the $L_{\mathrm{D}}$ inhibition on Hep G2 are distinctive when they are compared with the inhibition of the other imidazole-based chemicals on different cancer cell lines in the concerning studies. The $\mathrm{IC}_{50}$ values of the $L_{\mathrm{C}}$ on HeLa and the $L_{\mathrm{D}}$ on Hep G2 were $81 \mu \mathrm{M}$ and $57 \mu \mathrm{M}$, respectively. The similar imidazole compounds which have alkyl moieties were tested on the cancer cells different from the cells used in this study [8]. The $\mathrm{IC}_{50}$ values of 1-(benzofuran-2-yl (phenyl)methyl)-3-allyl-2-ethyl-1H-imidazol-3-ium bromide and 1-(benzofuran-2-yl(phenyl)methyl)-3-butyl-2-ethyl-1Himidazol-3-ium iodide on leukemia (HL-60), lung carcinoma (A549), colon carcinoma (SW480), breast carcinoma (MCF-7), and myeloid liver carcinoma (SMMC-7721) cancer lines have been detected over $40 \mu \mathrm{M}$. Additionally, the $\mathrm{IC}_{50}$ activity of 3 3 -hydroxy-21-(1H-imidazol-1-yl)pregna-5,16dien-20-one on prostate cancer (PC-3), breast cancer (MCF7), and lung cancer (SK-LU- 1) were $20 \mu \mathrm{M}, 19 \mu \mathrm{M}$, and $18 \mu \mathrm{M}$, respectively [7]. These results are quantitatively better than $81 \mu \mathrm{M}$ and $57 \mu \mathrm{M}$ on Hep G2 and HeLa. However, this is compensated by the fact that the $L_{\mathrm{C}}$ and $L_{\mathrm{D}}$ have not any harmful effect on the healthy MEF cell lines.

\section{Conclusions}

Novel imidazole salts, or $N$-heterocyclic carbene ligands, namely, 1,3-bis(2-hydroxyethyl) imidazolidinium bromide $L_{\mathrm{A}}$, 3-(2-ethoxy-2-oxoethly)-1-(3-aminopropyl)-1H-imidazol-3-ium bromide $L_{\mathrm{B}}, \quad$ 1,3-bis(2-carboxyethyl)-4-methyl-1H-imidazol-3ium bromide $L_{\mathrm{C}}$, and 3-(2-carboxyethyl)-1-(3-aminopropyl)$1 H$-imidazol-3-ium bromide $L_{\mathrm{D}}$ were synthesized, and they were preliminary confirmed by GC-MS and elemental analysis methods. Their molecular structures were theoretically determined, and they were confirmed by comparing calculated ${ }^{1} \mathrm{H}$, ${ }^{13} \mathrm{C}$ NMR, and IR spectra with those of experimentally observed data. Also, the calculated structures were verified by the XRD results on a similar imidazole salt [22].

The antimicrobial and cytotoxic activities of the synthesized ligands on some specific bacteria and cancer cell lines were measured using spectrophotometric methods. It is seen that $L_{\mathrm{A}}$ showed better inhibition than the selected antibiotic on Bacillus cereus ATCC 11778 while it is effective on the selected bacteria and the yeast together with $L_{\mathrm{B}}$. On the cytotoxicity evaluation, $L_{\mathrm{C}}$ showed considerable inhibition effect on HeLa, as does $L_{\mathrm{D}}$ on Hep G2. Although their $\mathrm{IC}_{50}$ doses are quite high in comparison with the similar chemicals in the literature, the cytotoxicity of $L_{C}$ and $L_{\mathrm{D}}$ is affirmed by not causing harmful effect on the healthy MEF cells as much as they do on the cancel cell lines.

\section{Data Availability}

The data used to support the findings of this study are available from the corresponding author upon request.

\section{Conflicts of Interest}

The authors declare that they have no conflicts of interest.

\section{References}

[1] X. Chen, Y. Zou, M. Han et al., "Solubilisation of myosin in a solution of low ionic strength L-histidine: significance of the imidazole ring," Food Chemistry, vol. 196, pp. 42-49, 2016.

[2] R. I. Benhamou, K. B. Steinbuch, and M. Fridman, "Antifungal imidazole-decorated cationic amphiphiles with markedly low hemolytic activity," Chemistry, vol. 22, no. 32, pp. 11148-11151, 2016.

[3] M. Y. Wani, A. Ahmad, R. A. Shiekh, K. J. Al-Ghamdi, and A. J. Sobral, "Imidazole clubbed 1,3,4-oxadiazole derivatives as potential antifungal agents," Bioorganic and Medicinal Chemistry, vol. 23, no. 15, pp. 4172-4180, 2015.

[4] K. Krowicki and J. W. Lown, "Synthesis of novel imidazolecontaining DNA minor groove binding oligopeptides related to the antiviral antibiotic netropsin," Journal of Organic Chemistry, vol. 52, no. 16, pp. 3493-3501, 1987.

[5] W.-N. Lee, A. Y.-C. Lin, and X.-H. Wang, "The occurrence of quinolone and imidazole antibiotics in rivers in Central Taiwan," Desalination and Water Treatment, vol. 52, no. 4-6, pp. 1143-1152, 2013.

[6] G. Castanedo, Y. Liu, J. J. Crawford, and M. G. Braun, "Synthesis of fused imidazole-containing ring systems via dual oxidative amination of $\mathrm{C}(\mathrm{sp}(3))-\mathrm{H}$ bonds," Journal of Organic Chemistry, vol. 81, no. 18, pp. 8617-8624, 2016.

[7] A. V. Silva-Ortiz, E. Bratoeff, M. T. Ramirez-Apan et al., "Synthesis and biological activity of two pregnane derivatives with a triazole or imidazole ring at C-21," Journal of Steroid Biochemistry and Molecular Biology, vol. 159, pp. 8-18, 2016.

[8] X.-Q. Wang, L.-X. Liu, Y. Li et al., "Design, synthesis and biological evaluation of novel hybrid compounds of imidazole scaffold-based 2-benzylbenzofuran as potent anticancer agents," European Journal of Medicinal Chemistry, vol. 62, pp. 111-121, 2013.

[9] A. Mrozek, J. Karolak-Wojciechowska, and K. Kieć-Kononowicz, "Five-membered heterocycles. Part III. Aromaticity of 1,3-imidazole in 5+n hetero-bicyclic molecules," Journal of Molecular Structure, vol. 655, no. 3, pp. 397-403, 2003.

[10] R. Boussessi, S. Dalbouha, V. Timón, N. Komiha, N. Jaïdane, and M. L. Senent, "Stability of Van der Waals complexes of the greenhouse effect gases $\mathrm{CH} 4$ and SF6 with imidazole in gas mixtures containing $\mathrm{CO}_{2}$," Computational and Theoretical Chemistry, vol. 1094, pp. 82-91, 2016.

[11] L. Feng, X. Zhang, C. Wang et al., "Effect of different imidazole group positions on the hydroxyl ion conductivity," International Journal of Hydrogen Energy, vol. 41, no. 36, pp. 16135-16141, 2016.

[12] G.-C. Zheng, Z.-B. Cai, Y.-L. Pan et al., "Synthesis and twophoton absorption properties of novel 2-substituted-4,5diphenyl-1H-imidazoles," Tetrahedron, vol. 72, no. 22, pp. 2988-2996, 2016.

[13] R. B. Campos, L. R. A. Menezes, A. Barison, D. J. Tantillo, and E. S. Orth, "The importance of methyl positioning and tautomeric equilibria for imidazole nucleophilicity," Chemistry-A European Journal, vol. 22, no. 43, pp. 15521-15528, 2016.

[14] A. J. Arduengo, R. L. Harlow, and M. Kline, "A stable crystalline carbene," Journal of the American Chemical Society, vol. 113 , no. 1, pp. 361-363, 1991.

[15] M. O. Karatas, B. Olgundeniz, S. Gunal, I. Ozdemir, B. Alici, and E. Cetinkaya, "Synthesis, characterization and antimicrobial activities of novel silver(I) complexes with coumarin substituted N-heterocyclic carbene ligands," Bioorganic and Medicinal Chemistry, vol. 24, no. 4, pp. 643-650, 2016. 
[16] H. A. Özbek, P. S. Aktaş, J.-C. Daran, M. Oskay, F. Demirhan, and B. Çetinkaya, "Synthesis, structure, electrochemical and antimicrobial properties of $\mathrm{N}, \mathrm{N}^{\prime}$-bis(ferrocenylmethyl)imidazolinium salts," Inorganica Chimica Acta, vol. 423, pp. 435-442, 2014.

[17] W. A. Herrmann, "N-heterocyclic carbenes: a new concept in organometallic catalysis," Angewandte Chemie International Edition, vol. 41, no. 8, pp. 1290-1309, 2002.

[18] N. Hadei, E. A. Kantchev, C. J. O’Brien, and M. G. Organ, "Electronic nature of N-heterocyclic carbene ligands: effect on the Suzuki reaction," Organic Letters, vol. 7, no. 10, pp. 1991-1994, 2005.

[19] J. S. Al-Otaibi and R. I. Al-Wabli, "Vibrational spectroscopic investigation (FT-IR and FT-Raman) using ab initio (HF) and DFT (B3LYP) calculations of 3-ethoxymethyl-1,4-dihydroquinolin-4-one," Spectrochimica Acta Part A: Molecular and Biomolecular Spectroscopy, vol. 137, pp. 7-15, 2015.

[20] J. B. Foresman and A. E. Frisch, Exploring Chemistry with Electronic Structure Methods, Gaussian, Inc., Wallingford, CT, USA, 2nd edition, 1996.

[21] G. Uluçam, S. E. Okan, Ş. Aktaş, and G. P. Öğretmen, "Characterization of dinaphthosulfoxide molecule," Journal of Molecular Structure, vol. 1102, pp. 146-152, 2015.

[22] M. Turkyilmaz, G. Uluçam, Ş. Aktaş, and S. E. Okan, "Synthesis and characterization of new $\mathrm{N}$-heterocyclic carbene ligands: 1,3-Bis(acetamide)imidazol-3-ium bromide and 3(acetamide)-1-(3-aminopropyl)-1H-imidazol-3-ium bromide," Journal of Molecular Structure, vol. 1136, pp. 263-270, 2017.

[23] X. Mi, S. Luo, and J.-P. Cheng, "Ionic liquid-immobilized quinuclidine-catalyzed Morita-Baylis-Hillman reactions," Journal of Organic Chemistry, vol. 70, no. 6, pp. 2338-2341, 2005.

[24] X. Mi, S. Luo, H. Xu, L. Zhang, and J.-P. Cheng, "Hydroxyl ionic liquid (HIL)-immobilized quinuclidine for BaylisHillman catalysis: synergistic effect of ionic liquids as organocatalyst supports," Tetrahedron, vol. 62, no. 11, pp. 25372544, 2006.

[25] J. Sasaki, J. K. Lanyi, R. Needleman, T. Yoshizawa, and A. Maeda, "Complete identification of C:O stretching vibrational bands of protonated aspartic acid residues in the difference infrared spectra of $\mathrm{M}$ and $\mathrm{N}$ intermediates versus bacteriorhodopsin," Biochemistry, vol. 33, no. 11, pp. 31783184, 1994.

[26] L. Clougherty, J. Sousa, and G. Wyman, "Notes-C=N stretching frequency in infrared spectra of aromatic azomethines," Journal of Organic Chemistry, vol. 22, no. 4, p. 462, 1957.

[27] S. Gunasekaran, E. Sailatha, S. Seshadri, and S. Kumaresan, "FTIR, FT Raman spectra and molecular structural confirmation of isoniazid," Indian Journal of Pure and Applied Physics, vol. 47, no. 1, pp. 12-18, 2009.

[28] M. Schwanninger, J. C. Rodrigues, H. Pereira, and B. Hinterstoisser, "Effects of short-time vibratory ball milling on the shape of FT-IR spectra of wood and cellulose," Vibrational Spectroscopy, vol. 36, no. 1, pp. 23-40, 2004.

[29] J. S. Singh, "FT-IR and Raman spectra, ab initio and density functional computations of the vibrational spectra, molecular geometries and atomic charges of uracil and 5-methyluracil (thymine)," Spectrochimica Acta Part A: Molecular and Biomolecular Spectroscopy, vol. 137, pp. 625-640, 2015. 

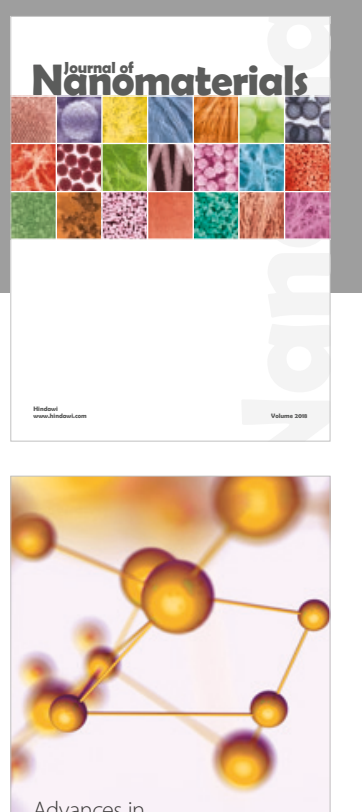

Physical Chemistry
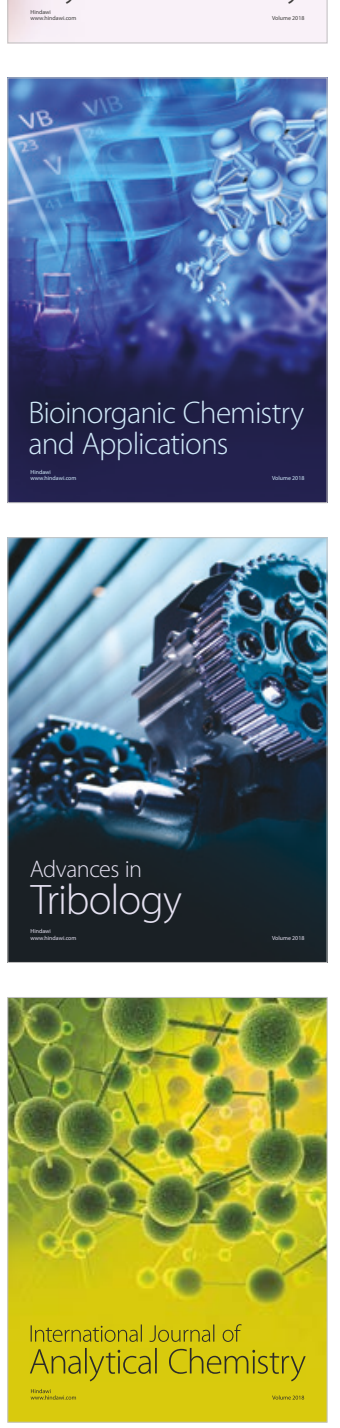

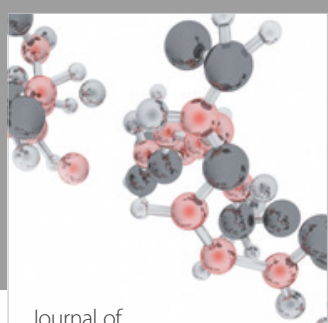

Analytical Methods

in Chemistry

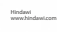

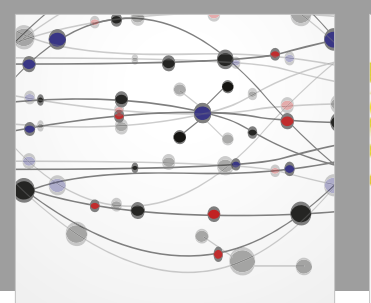

The Scientific World Journal

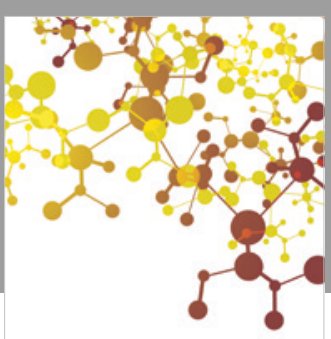

Journal of

Applied Chemistry
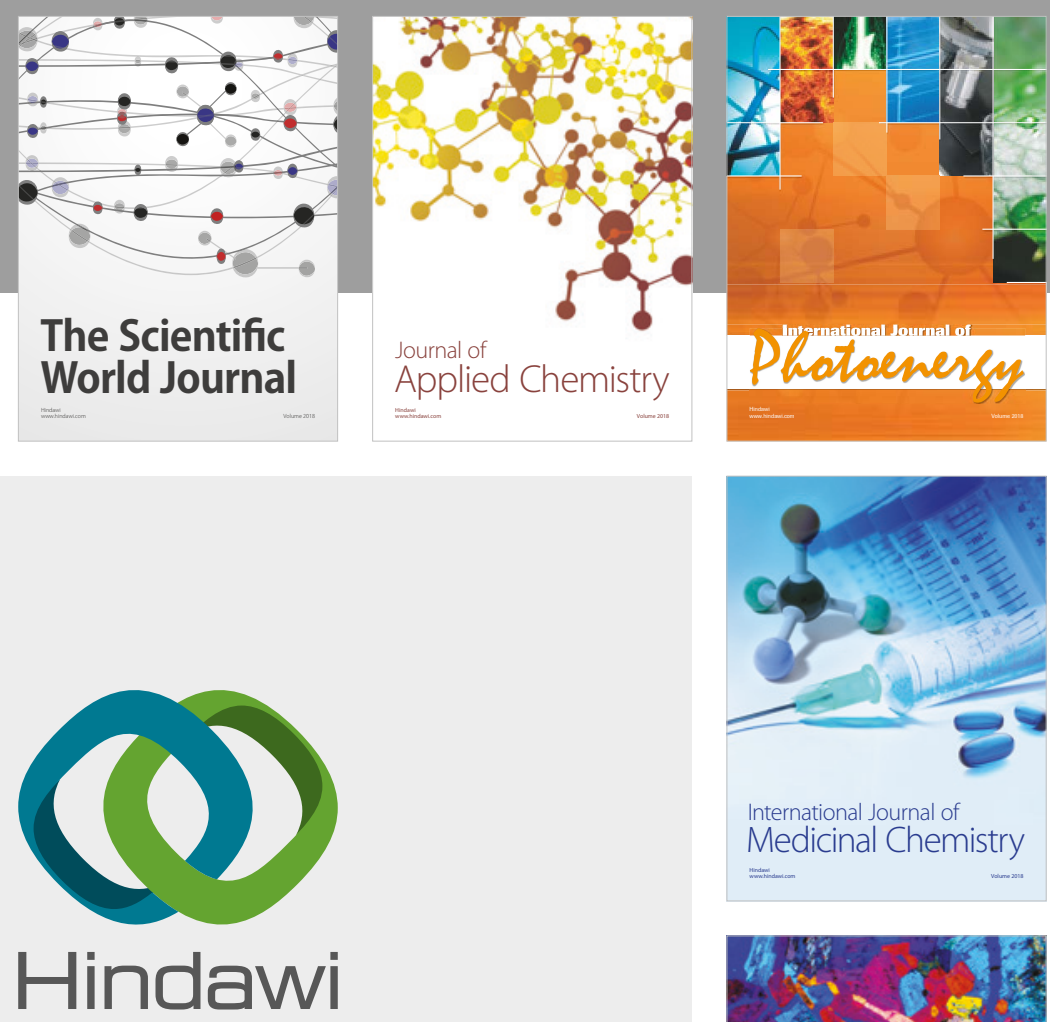

Submit your manuscripts at

www.hindawi.com
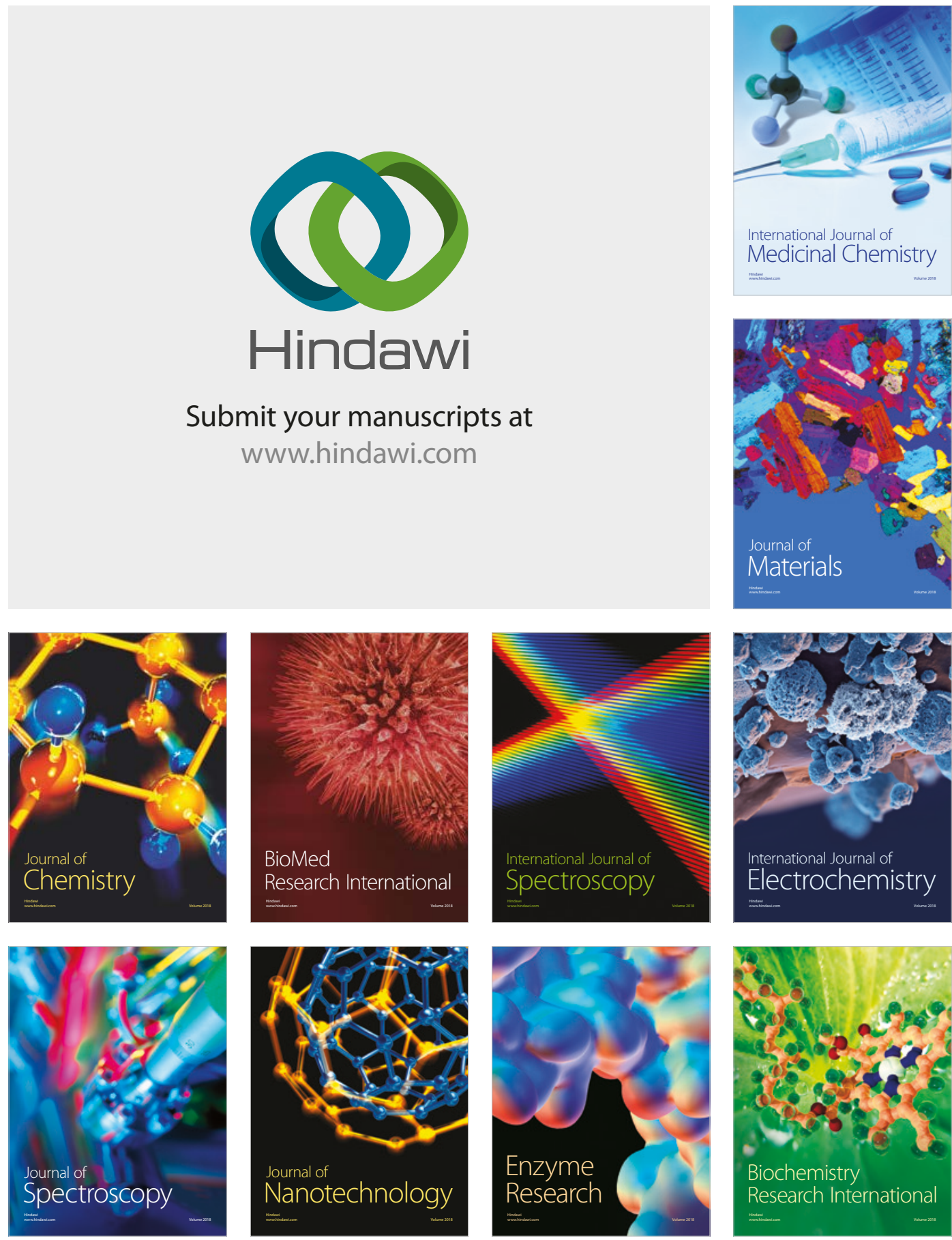
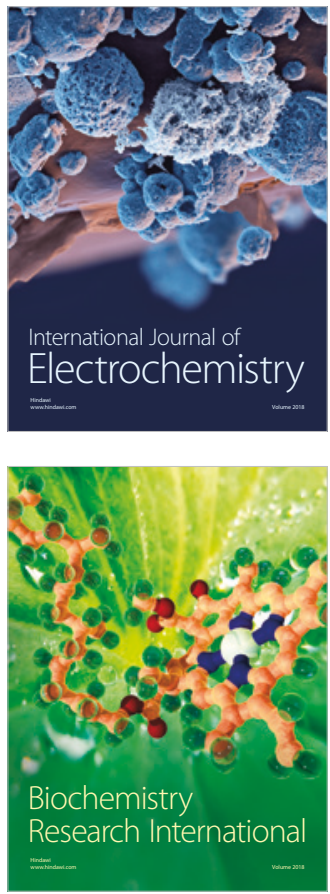